\title{
Characterization of structural failures founded on soils in Panyam and some parts of Mangu, Central Nigeria
}

\author{
Ogbonnaya Igwe ${ }^{1}$ and Allu Augustine Umbugadu ${ }^{2 *}$
}

\begin{abstract}
Structural failure of buildings, roads, and other infrastructures has led to the loss of lives and monumental damage to the economy. In developing countries such as Nigeria, the failures are always attributed to the nature/type of soils in the area without considering other factors. With the increase in civil engineering constructions and the scramble for a limited portion of competent soils for such constructions, land, therefore, is becoming man's most priced commodity for agriculture, residential and industrial purposes. No works of such have been done in the area, it is, therefore, imperative to study the cause(s) to prevent further loss of lives and the negative effects of such on the economy. The study was carried out at Panyam and some surrounding localities on latitudes $N 9^{\circ} 21^{\prime}$ and $\mathrm{N}^{\circ} 26^{\prime}$ and longitudes $9^{0} 11^{\prime} \mathrm{E}$ and $9^{\circ} 16^{\prime} \mathrm{E}$ an area of $72 \mathrm{~km}^{2}$. A total of forty samples were collected out of which twenty were selected for swelling potentials determination due to their cohesive nature within the $1.5 \mathrm{~m}$ depth. To characterize the swelling of the soils, inferential testing methods; direct method comprising Liquid Limit and Plasticity Index with values ranging from 30\% - 70\% and 10\% - 27\% respectively, and the indirect method (Free Swell Index, FSI) whose values range from $9.1 \%$ - 90\% were used. Most of the soils analyzed based on the geotechnical standards were categorized relatively safe for civil infrastructure. Structural studies employed the direct measurements of surface structures to get the orientations of structures measured. Landsat image and Total Magnetic Intensity (TMI) map of the area was acquired from the Nigerian Geological Survey Agency (NGSA) for subsurface structural analysis. The RTP-TMI (reduce to pole) grid data of the area were processed to improve magnetic anomalies associated with edges of surface/near-surface geological structures using the MAGMAP twodimensional fast fourier transform (2D-FFT) filters package in Oasis Montaj v7.2 software. Geophysical studies using aeromagnetic data at a near-surface depth of $40 \mathrm{~m}$ and fractures measured on the surface both revealed a major trend in the NNE - SSW. It was observed that structures constructed across the major trend suffered little to moderate damage while those constructed along the major fractures trend suffered severe damage. It was concluded that both soils and fractures played individual roles in the collapse of infrastructure in the area.
\end{abstract}

Keywords: Free swell index, Reduce to pole, Total magnetic intensity, Liquid limit, Plasticity index

\section{Introduction}

Structural failure of buildings, roads and other infrastructures has led to the loss of lives and monumental damage to the economy. In developing countries such as Nigeria, structural failures are always attributed to the nature/type of soils in the area without considering other factors. With the increase in civil engineering constructions and the scramble

\footnotetext{
* Correspondence: umbugaduallu@nsuk.edu.ng

${ }^{2}$ Faculty of Natural and Applied Sciences, Nasarawa State University, Keffi, Nigeria

Full list of author information is available at the end of the article
}

for a limited portion of competent soils for such constructions, land, therefore, is becoming man's most priced commodity for agriculture, residential and industrial purposes.

In America, the American Society of Civil Engineers estimates that one in four homes have some damage caused by expansive soils. In a typical year, expansive soils cause a greater financial loss to property owners than earthquakes, floods, hurricanes and tornadoes combined (Nelson and Miller 1992).

The effect of soil shrinkage and swelling causing damage to infrastructures in the United Kingdom were properly 
studied and loses in billions of pounds (Driscoll and Crilly 2000) were recorded. In the US, the estimated damage to buildings and infrastructure exceeds $\$ 15$ billion annually. Such data in developing nations like Nigeria would be difficult because of poor handling of data and sometimes not understanding the cause of the problem.

Thomas et al. (2000) discussed the importance of classifying soils based on the clay content and they further described the need to use a combination of methods to obtain proper estimates of swelling potential. Others have designed classification schemes based on two or three indices where discrete thresholds are used to group the soils into swelling potential, Holtz (1969) who developed classification schemes, which combine engineering properties and cation exchange capacities to classify soils in terms of swelling potential and the dominant clay minerals. Thomas et al. (2000) used summation of indices to obtain three swelling potentials to characterize soils.

The swelling behaviour of soils has a direct relation to clay type and amount of clay minerals present in the soil (Elarabi 2004; Azam et al. 2013). The quantity of clay minerals in soil mainly depends on the type of parent material and the degree or nature of chemical weathering. The swelling of soils, of course, results in the uplift of the ground surface, while the shrinking normally causes settlement of the ground surface as well as the infrastructures on it (Freeman et al. 1991; Fityus et al. 2009; Mokhtari and Dehghani 2012). The reality that swelling and shrinkage are only partly recoverable, the undesirable effects caused on infrastructures are equally not reversible (Holtz and Kovacs 1981). It is of interest to identify the existence and study the potential problems that may be caused by expansive soils before construction so that adequate designs are identified that will deal with expansive soil problems rather than waiting for costly remedial measures after construction.

The Pan African Orogeny leads to deformation, whose imprint has been widely recognized in Precambrian rocks of Nigeria (Rahaman 1988). Regional metamorphism was one of these events which accompanied the Pan-African deformation. This has resulted in the formation of structures such as faulting and fracturing, folding, jointing, veins, intrusions, foliation and mineral lineation. The structural elements observed in the area include foliation, faults and veins. The orientation of fractures were plotted in form of Rosette diagram which is used here to evaluate the portion of the tectonic forces that affected rocks in the study area and characterize the extent of the deformation.

The Benue Rift commonly referred to as the Benue Trough, is an intra-continental rift which developed during the second phase of rifting of the Gondwana supercontinent that resulted in the opening of the South Atlantic Ocean, Gulf of Guinea and the separation of South America from Africa in the Late Jurassic to Early Cretaceous (Carter 1963; Cratchley and Jones 1965; Wright 1976, 1981; Benkhelil et al. 1989; Janssen et al. 1995;). It is the third 'failed arm' (or aulacogen) of the three-armed rift system associated with the initial opening of the South Atlantic Ocean (Burke and Whiteman

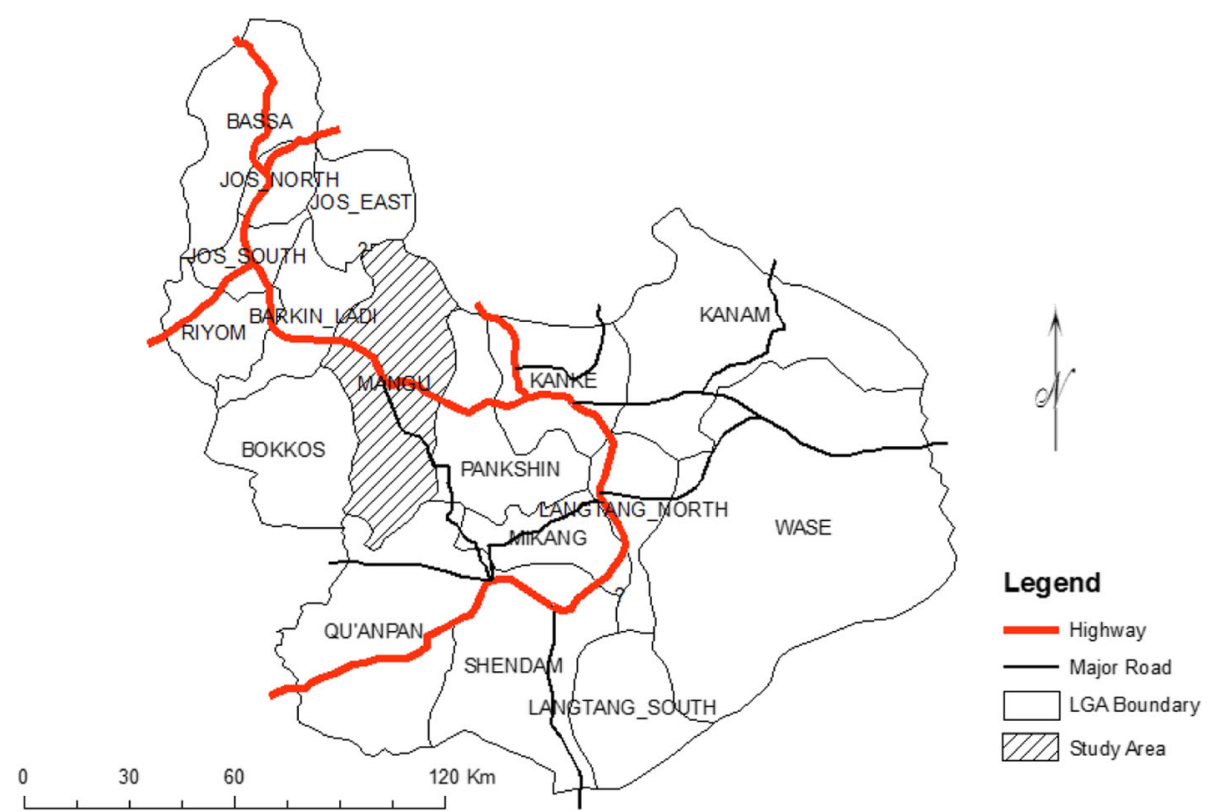

Fig. 1 Map of plateau state showing study area 
1973; Burke and Dewey 1974; Olade 1975; Whiteman 1982; Fairhead and Binks 1991). According to Benkhelil (1982), the structural evolution of the Trough may be attributed to the extension of the Atlantic Ocean fracture zones onto the continent through transcurrent movements along deep-seated basement faults. The Benue Trough is also an integral part of the West and Central African Rift System (WCARS; Fairhead 1986; Schull 1988; Genik 1992; Guiraud and Maurin 1992). It starts from the northern end of the Niger Delta Basin in the south and extends to the Bornu Basin in the east from where it joins the other African intra-continental rift system of Chad, Niger, Cameroon and Sudan. It is about $1000 \mathrm{~km}$ long, $120-150 \mathrm{~km}$ wide, contains up to $6 \mathrm{~km}$ thick Cretaceous (Aptian-Albian to Maastrichtian) sedimentary rocks and trends in the NE-SW direction resting unconformably upon the Precambrian crystalline basement (Benkhelil 1989; Benkhelil et al. 1989). The
Trough is partitioned into the lower, middle, and upper segments based on tectonic and sedimentary characteristics (Ofoegbu 1984; Benkhelil 1989;) (Fig. 4).

\section{Location and geology of study area}

The study area falls within the Basement Complex of Nigeria. The geology of Nigeria is made up of three major litho-petrological components, namely, the Basement Complex, the Younger Granites and the Sedimentary Basins. The Basement Complex which is widely accepted to be dating back to Precambrian age, is made up of the Migmatite-Gneiss Complex, the Schist Belt and the Older Granites. The Younger Granites comprise of several Jurassic Migmatite ring Complex centered around Jos and other parts of north-central Nigeria (Obaje 2013).

The study area lies within Pankshin Sheet 190 in Plateau State of Nigeria and is located in Mangu Local Government Area (LGA). The area lies between

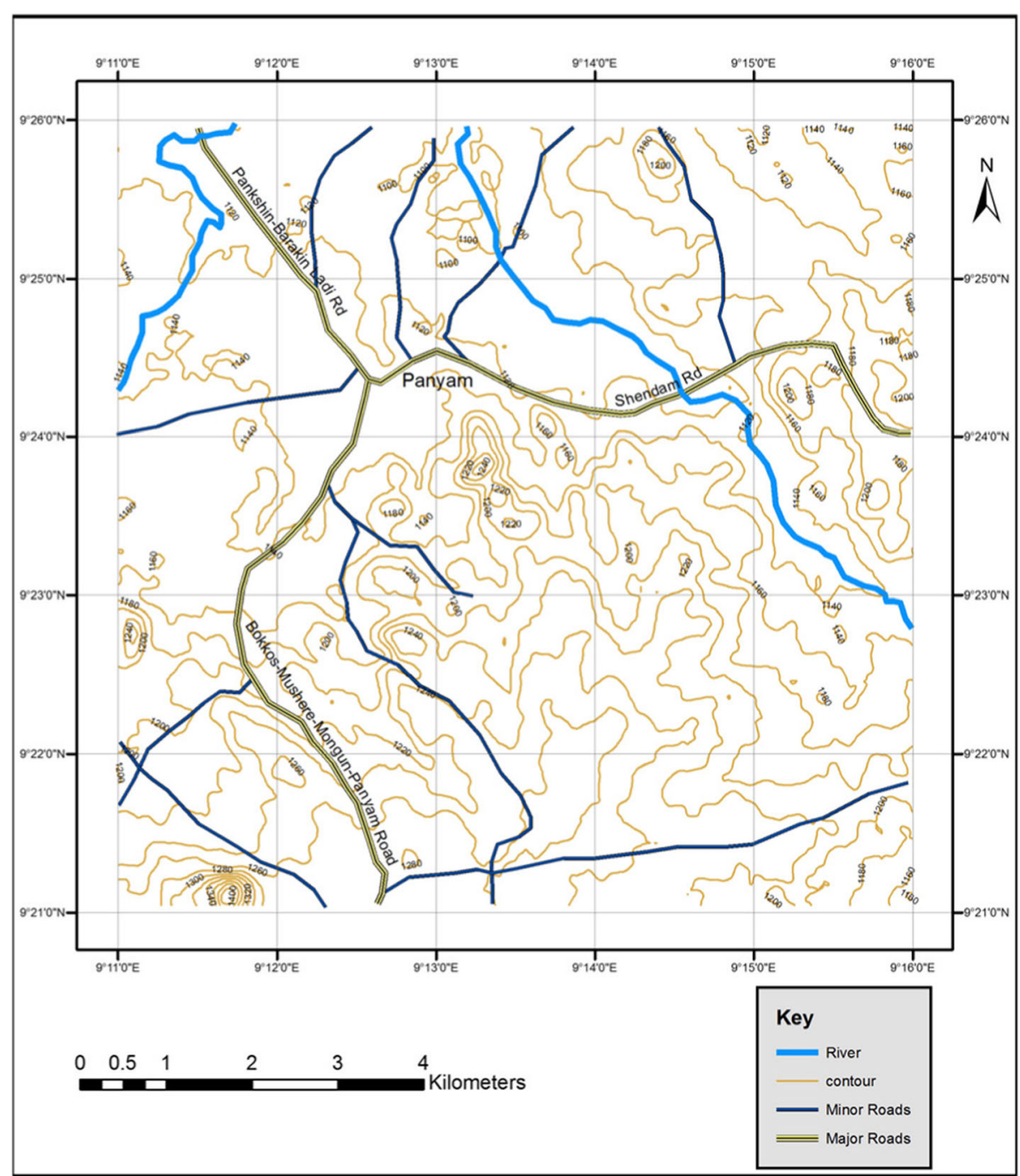

Fig. 2 Topographic Map of the Study Area 
Latitudes $9^{\circ} 21^{\prime} \mathrm{N}$ and $9^{\circ} 26^{\prime} \mathrm{N}$ and Longitudes $9^{\circ} 11^{\prime} \mathrm{E}$ and $9^{\circ} 16^{\prime} \mathrm{E}$ (Figs. 1 and 2). The study area covers an area of seventy-two (72) square kilometres $\left(\mathrm{km}^{2}\right)$.

Geologically, the area is composed of four major rock units, which can chronologically be listed as Granite gneiss, fine/medium-grained biotite granite, older basalt and newer basalts. While the granite gneiss are the oldest rocks which is part of the basement complex series, the fine to medium grained biotite granite are of the Jurassic non-orogenic alkaline younger granite series. The older and younger basalts are Tertiary and Quaternary volcanics, respectively. The basalts are distinguished on the basis of their period of emplacement and textural differences (Macleod 1971; Lar and Tsalha 2005). The older basalts occur as decomposed boulders, plugs or dome-like outcrops, while the newer basalts occur as cones and lava flows (Lar and Tsalha 2005).

Spatially, the newer basalt occupies about $85 \%$ of the area covering the Northern portion of the studied area. The fine to medium-grained biotite granite occupies about $10 \%$ of the area occurring along the entire southern portion of the studied area. The granite gneiss which covers about $4 \%$ occurs along the southwestern part of the area while the remaining $1 \%$ of the area far north is occupied by the older basalt (Fig. 3). Given their relative ages, the basalts overlie directly the granitic rocks.

The causes of structural failure in Nigeria are numerous and can be complex depending on the type and complexity of the structure (Wasiu et al. 2014). About sixty (60) buildings that collapsed and were studied in the country from 1974 to 2006, revealed that poor maintenance culture, design error, poor quality of materials and workmanship, natural phenomenon and excessive loading contributed to about 7\%, 15\%, 52\%, $7 \%$ and $20 \%$ respectively of building collapse in Nigeria (Olayinka et al. 2017).

None of all the reported cases of building collapse in Nigeria has direct link to sub-surface fractures hence the need for the characterization of structural failures in Panyam and some parts of Mangu, Central Nigeria, was borne out of commitment to study the cause(s) of structural collapse mostly of roads and buildings in the areas.

\section{Methodology}

A total number of forty disturbed soil samples derived from the weathering of granites and basalts were collected from the study area (i.e. Mangu, north central Nigeria) out of which twenty representative samples

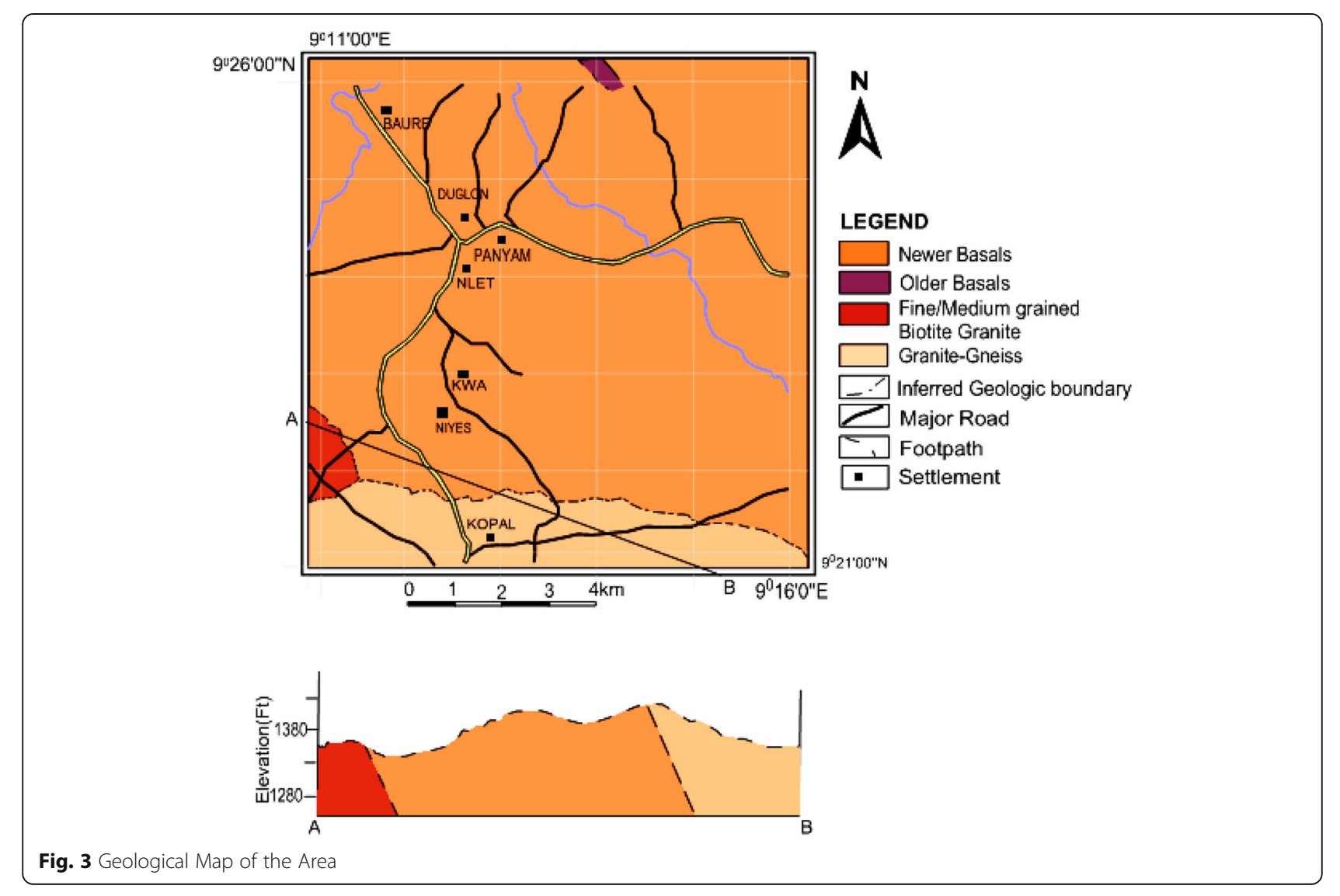


with high clay fraction with swelling potential were selected after geotechnical analysis. Sampling sites were carefully chosen reflecting the physiographic zones of the area; high ground and plains (Food and Agricultural Organization 1998). The samples were collected at 1.5 $m$ depth at over $72 \mathrm{~km}^{2}$ to properly represent a wide variation in swelling properties and different parent materials that would constitute mainly of volcanic and basement rocks. The samples were collected by random sampling adhering to the British Standards (BS) 1377 method of sampling and were labeled UAA. Structural analysis from both landsat image and aeromagnetic data were processed to study both surface and subsurface linear structures to ascertain its connections to structural failures or otherwise in the area.

The soils sampled were taken to the Nigerian Geological Survey Agency to analyze for Atterberg limits, grain size distribution, Free swell index (FSI) and compaction. The determination of FSI as adopted by the IS: 2720, Part 40 1977, involved taking two $10 \mathrm{~g}$ of ovendried soil samples passing through the $425 \mathrm{4m}$ sieve. Each sample was placed separately in two $100 \mathrm{ml}$ graduated cylinders, one containing distilled water and the other kerosene (non-polar liquid) filled to the $100 \mathrm{ml}$ mark. The final volume of soil was read after $24 \mathrm{~h}$ to calculate the free swell index as follow:

Free swell value in $(\%)=\mathrm{V} / \mathrm{Vo} \times 100$

Where $\mathrm{V}=$ final volume (volume in water) $\mathrm{Vo}=$ initial volume (volume in kerosene)

The Atterberg limits and compaction tests were conducted by the methods described in British Standards 1377 (1990). A portion of the mixed soil for liquid limit determination using the Casagrande's apparatus was pushed into the cup with a palette knife ensuring no air was trapped. Excess soil was stroke off with the straightedge for a smooth level surface. The penetration cone was locked in the raised position so that the tip of the cone just touches the surface of the soil. After the cone was in the correct position, a slight movement of the cup will mark the soil surface. The stem of the dial gauge was lowered to contact the cone shaft and record the reading of the dial gauge to the nearest $0.1 \mathrm{~mm}$. The cone was then released for a period of $5 \pm 1 \mathrm{~s}$. After locking the cone in position, the stem of the dial gauge was lowered to contact the cone shaft and record the reading of the dial gauge to the nearest $0.1 \mathrm{~mm}$. The difference between the beginning and end of the drop as the cone penetrated the soil was recorded. The procedure was repeated four times.

For the plastic limit (PL), about $20 \mathrm{~g}$ of soil sample, passing $0.425 \mathrm{~mm}$ sieve was used for the test. The sample was thoroughly mixed with distilled water and

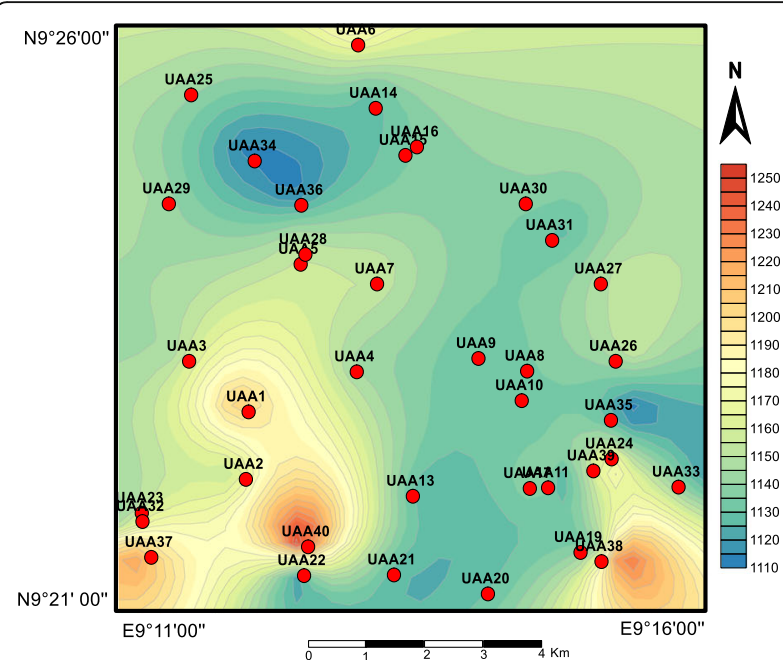

a:

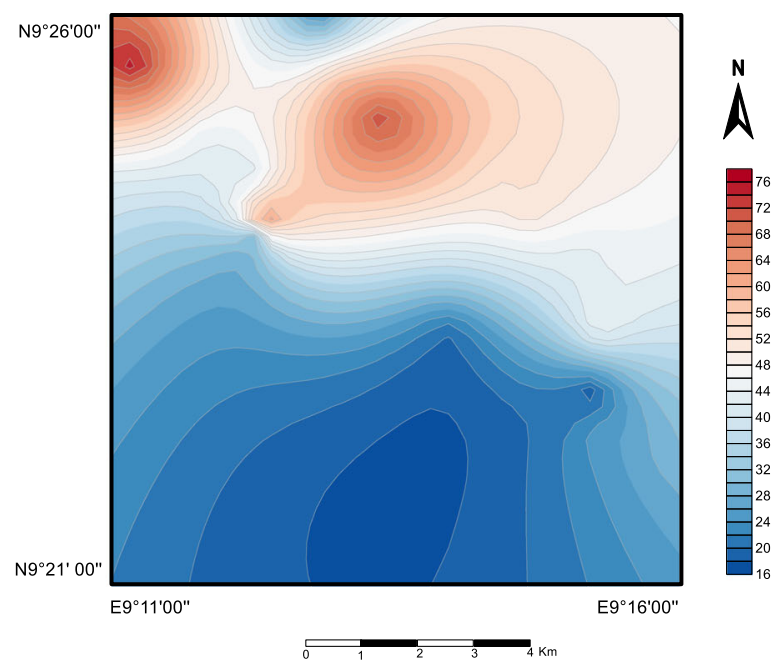

b:

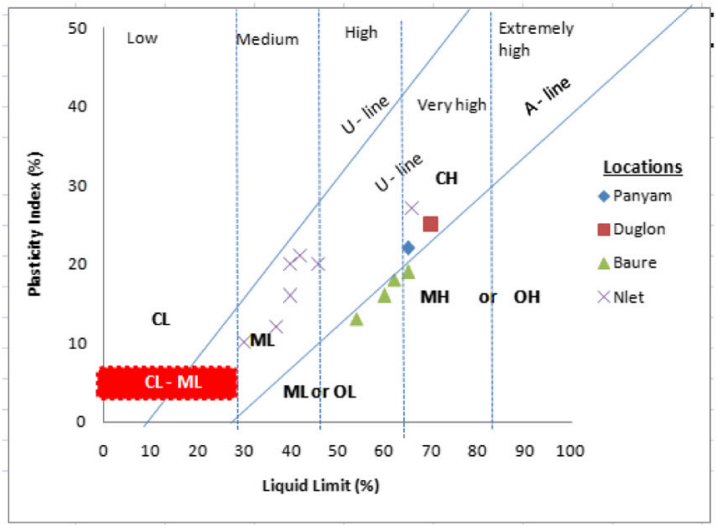

c:

Fig. 4 a Figure showing sampling distribution in the area. b Figure showing the distribution of clay fraction in the area. c Plasticity chart of cohesive soils of the area 
kneaded for about $10 \mathrm{~min}$ to form a plastic ball. The ball was molded between the fingers and rolled between the palms, such that the warmth from the hand slowly dried it. When slight cracks began to appear at the surface the ball was divided into two portions each of about $10 \mathrm{~g}$, it was further divided into four parts with each set of four parts kept together. One of the parts was formed into a thread of about $6 \mathrm{~mm}$ diameter using the finger and the thumb. The thread was then rolled between the fingers and a glass plate using steady pressure which reduced the diameter to about $3 \mathrm{~mm}$, the pressure was maintained until the thread crumbled. This crumbling point is the plastic limit. The crumbled pieces were collected and placed in a weighed can and weighed as quickly as possible. The can with soil was placed in the oven to dry at a temperature of $105-110^{\circ} \mathrm{C}$ overnight. It was then cooled and weighed. The procedure was repeated with the other set of four portions using a second container.
The moisture content of the soil in each of the two containers was calculated (like in liquid limit) and the average reported as the plastic limit.

The digital aeromagnetic data used in the study are from the recent high-resolution national datasets flown by Fugro Airborne Surveys in 2006 and 2007 for the Nigerian Geological Survey Agency (NGSA). Equipment employed during the data acquisition includes a fixed-wing aircraft, 3_Sintrex CS3 CaesiumVapour magnetometer, FASDAS magnetic counter, KING KR 405/KING KR 405B radar altimeter and ENVIRO BARO/DIGIQUARTZ barometric altimeter. The aeromagnetic survey was flown along with a series of NW-SE flight lines (i.e. perpendicular to dominant regional geological strike), spaced $500 \mathrm{~m}$, with 2000 mtie-line spacing in a NE-SW direction and $80 \mathrm{~m}$ nominal flight height. Data were recorded at $0.1 \mathrm{~s}$ interval. Since the aeromagnetic survey was

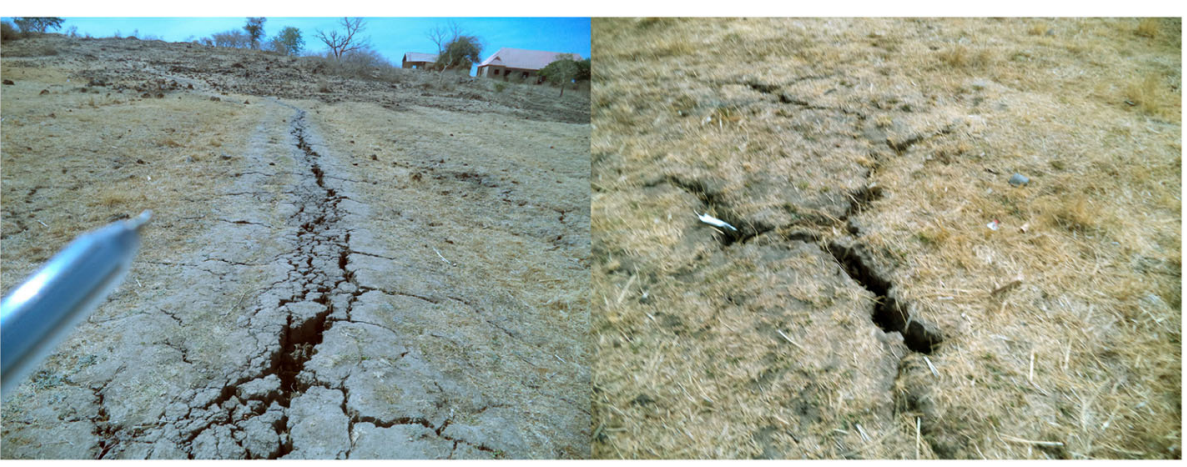

a

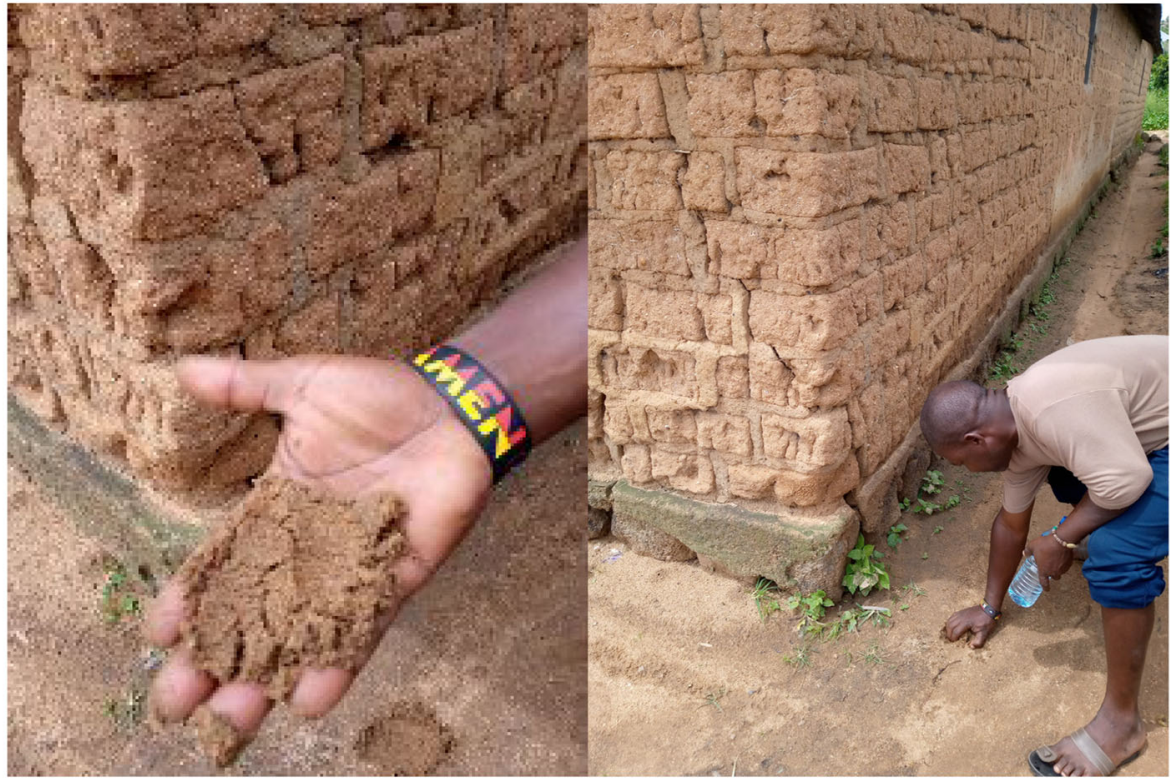

b

Fig. 5 a Typical cohesive soils $\mathbf{b}$ ) cohesionless soil of the area 


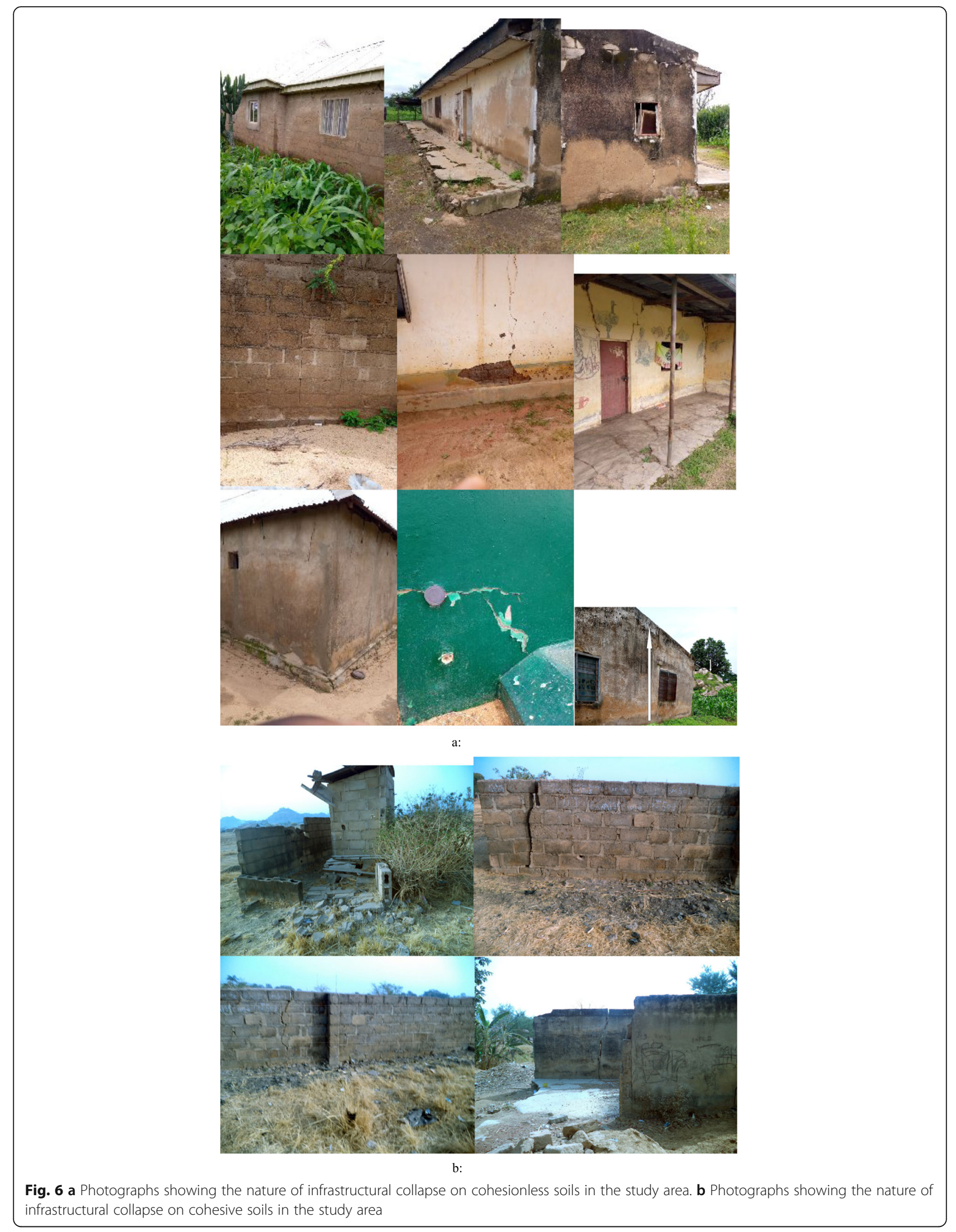


Table 1 Geotechnical parameters of soils in the study area

\begin{tabular}{|c|c|c|c|c|c|c|c|c|c|c|c|}
\hline \multirow[t]{2}{*}{ Sample ID } & \multirow{2}{*}{$\begin{array}{l}\text { Specific } \\
\text { gravity }\end{array}$} & \multicolumn{4}{|c|}{ Particle Size Analysis (\%) } & \multicolumn{3}{|c|}{ Consistency Limits } & \multicolumn{2}{|c|}{ Compaction Characteristics } & \multirow{2}{*}{$\begin{array}{l}\text { Swelling Paramete } \\
\text { Free swell } \\
\text { index (\%) }\end{array}$} \\
\hline & & Gravel & Sand & Silt & Clay & $\begin{array}{l}\text { Liquid limit } \\
(\%)\end{array}$ & $\begin{array}{l}\text { Plastic Limit } \\
(\%)\end{array}$ & $\begin{array}{l}\text { Plasticity Index } \\
(\%)\end{array}$ & $\begin{array}{l}\text { Optimum } \\
\text { moisture } \\
\text { content } \\
(\%)\end{array}$ & $\begin{array}{l}\text { Maximum Dry } \\
\text { Density } \\
\left(\mathrm{Mg} / \mathrm{m}^{3}\right)\end{array}$ & \\
\hline UAA 3 & 2.62 & - & 20 & 47 & 33 & 40 & 24 & 16 & 20.0 & 1.54 & 26.9 \\
\hline UAA 4 & 2.63 & - & 08 & 68 & 24 & 37 & 25 & 12 & 24.5 & 1.54 & 14.4 \\
\hline UAA 5 & 2.63 & 1 & 11 & 57 & 31 & 42 & 21 & 21 & 22.5 & 1.52 & 29.2 \\
\hline UAA 6 & 2.63 & - & 16 & 61 & 23 & 54 & 41 & 13 & 21.5 & 1.56 & 13.3 \\
\hline UAA 9 & 2.63 & - & 14 & 62 & 20 & 30 & 20 & 10 & 15.0 & 1.80 & 09.1 \\
\hline UAA 14 & 2.70 & - & 10 & 33 & 57 & 65 & 46 & 19 & 28.5 & 1.44 & 59.1 \\
\hline UAA 15 & 2.71 & - & 08 & 21 & 70 & 65 & 33 & 22 & 31.0 & 1.43 & 80.0 \\
\hline UAA 16 & 2.72 & - & 10 & 18 & 72 & 70 & 45 & 25 & 30.0 & 1.40 & 85.0 \\
\hline UAA 24 & 2.62 & - & 12 & 65 & 25 & 66 & 39 & 27 & 20.0 & 1.62 & 23.1 \\
\hline UAA 25 & 2.72 & - & 09 & 15 & 76 & 40 & 20 & 20 & 25.7 & 1.47 & 35.0 \\
\hline UAA 26 & 2.69 & - & 10 & 46 & 44 & 46 & 26 & 20 & 26.0 & 1.46 & 46.2 \\
\hline UAA 27 & 2.69 & - & 12 & 45 & 43 & 60 & 44 & 16 & 28.0 & 1.47 & 46.2 \\
\hline UAA 28 & 2.70 & - & 08 & 27 & 65 & 47 & 26 & 21 & 32.5 & 1.44 & 65.4 \\
\hline UAA 29 & 2.65 & - & 07 & 50 & 43 & 43 & 22 & 21 & 26.0 & 1.44 & 38.5 \\
\hline UAA 30 & 2.70 & - & 10 & 38 & 52 & 49 & 26 & 23 & 27.1 & 1.44 & 54.2 \\
\hline UAA 31 & 2.69 & - & 10 & 38 & 52 & 50 & 34 & 26 & 13.8 & 1.84 & 50.0 \\
\hline UAA 33 & 2.62 & - & 13 & 58 & 29 & 42 & 20 & 22 & 19.8 & 1.55 & 26.9 \\
\hline UAA 34 & 2.70 & 4 & 06 & 45 & 45 & 52 & 31 & 21 & 16.2 & 1.77 & 50.0 \\
\hline UAA 35 & 2.62 & - & 12 & 70 & 18 & 62 & 44 & 18 & 26.8 & 1.45 & 15.0 \\
\hline UAA 36 & 2.67 & 2 & 06 & 49 & 43 & 54 & 32 & 22 & 25.80 & 1.48 & 41.6 \\
\hline
\end{tabular}

flown close to the ground ( $80 \mathrm{~m}$ flight height) with narrow line spacing and very small recording inter$\mathrm{val}$, the resolution of the anomalies is vastly superior to that of conventional high-altitude aeromagnetic surveys. All necessary magnetic data corrections were carried out by Fugro Airborne Surveys. The geomagnetic gradient was removed using the January 2005 International Geomagnetic Reference Field (IGRF) model referenced to the World Geodetic System 1984 ellipsoid. The aeromagnetic data were georeferenced to the Universal Transverse Mercator (UTM) coordinate system for comparative study with a geological map of the area. The aeromagnetic (total magnetic intensity, TMI) data of the area were gridded using a bi-directional gridding method, which is ideal for parallel or nearly parallel oriented data to strengthen trends perpendicular to the flight lines. It uses Akima splines to interpolate data readings down-lines and across-lines to determine the values at the grid nodes (Akima 1970; Geosoft Inc 2012). A grid cell size of $100 \times 100 \mathrm{~m}$ was used, which is one-fifth $(1 / 5)$ of the survey or flight line spacing, so as to avoid short-wavelength errors that may appear as lines perpendicular to the line direction. According to Dentith (2011), grid cell size (i.e. distance between interpolated locations or positions) should be $1 / 3$ to $1 / 5$ of the survey line spacing.

The TMI grid data were then transformed using the reduction to the equator (RTE) filter, instead of the reduction to the pole (RTP) filter, since the study area is located within the low magnetic latitudes (i.e. areas with geomagnetic inclination less than 15) where a satisfactory reduction to the pole (RTP) of magnetic data is not possible (Sheriff 2002; Rajagopalan 2003; Wijins et al. 2005;

Table 2 Expansive soil classification based on liquid limit

\begin{tabular}{lll}
\hline Swell Potential & \multicolumn{2}{l}{ Liquid Limit (\%) } \\
\cline { 2 - 3 } & Chen (1965) & Snethen et al. (1977) \\
\hline Low & $<30$ & $<50$ \\
Medium/marginal & $30-40$ & $50-60$ \\
High & $40-60$ & $>60$ \\
Very High & $>60$ & - \\
\hline
\end{tabular}


Fairhead and Williams 2006; GETECH Group Plc 2007; Geosoft Inc 2011). Also a Butterworth low-pass filter was applied during the RTE transformation to eliminate highwavenumber associated with noise in the data. Parameters of the RTE filter are geomagnetic inclination of -8.571 , geomagnetic declination of -1.779 , and amplitude correction of -20 , whereas the Butterworth low-pass filter parameters include: cut-off wavelength of $500 \mathrm{~m}$ and filter order of 8 . The -8.571 and -1.779 are mean values of the geomagnetic inclination and declination, respectively computed for the area based on the IGRF-11 model for year 2006-2007 as adopted by the International Association of Geomagnetism and Aeronomy (IAGA) (NOAA/ NGDC 2010). This transforms the TMI anomaly map of the area into one with more precise directions of magnetisation and ambient field. It results in minor enhancements and relocations of magnetic anomalies on the original TMI anomaly map. Matched bandpass filtering has long been used to separate potential-field data into anomaly components representing different source depths (Phillips 2001). Spector (1968) was the first to implement such filtering using both Fourier and spatial domain techniques. Syberg (1972) afterward, included modeling of the azimuthal variations within each bandpass. Recently, Ridsdill-Smith (1998) implemented matched bandpass filtering using wavelet theory.
In the electrical resistivity survey method, current was being made to pass through the ground using direct current or a low-frequency AC. This was achieved by placing a pair of a current electrode at different distances $A B$ into the earth. Another pair of Potential electrodes was sent down into the ground at distances $\mathrm{MN}$ in between the two current electrodes and measurement of the potential difference generated by the current was recorded by the ABEM Terrameter. The Vertical Electrical Sounding (VES) method was adopted because it gives good information on depth because it is believed that there is a corresponding change in potential difference measured as the pair current electrodes on the surface is been spread apart thereby resulting in different layer resistivity values with depth. The potential electrode was also been increased at intervals to at most $1 / 5$ of the current electrode spacing to enable it contains the resulting currents being generated. Nine (9) VES points were investigated using the Schlumberger configuration.

\section{Results and discussions}

The samples presented revealed the presence of clay minerals like Illite, montmorillonite and some of the clay minerals (Umbugadu and Igwe 2019).

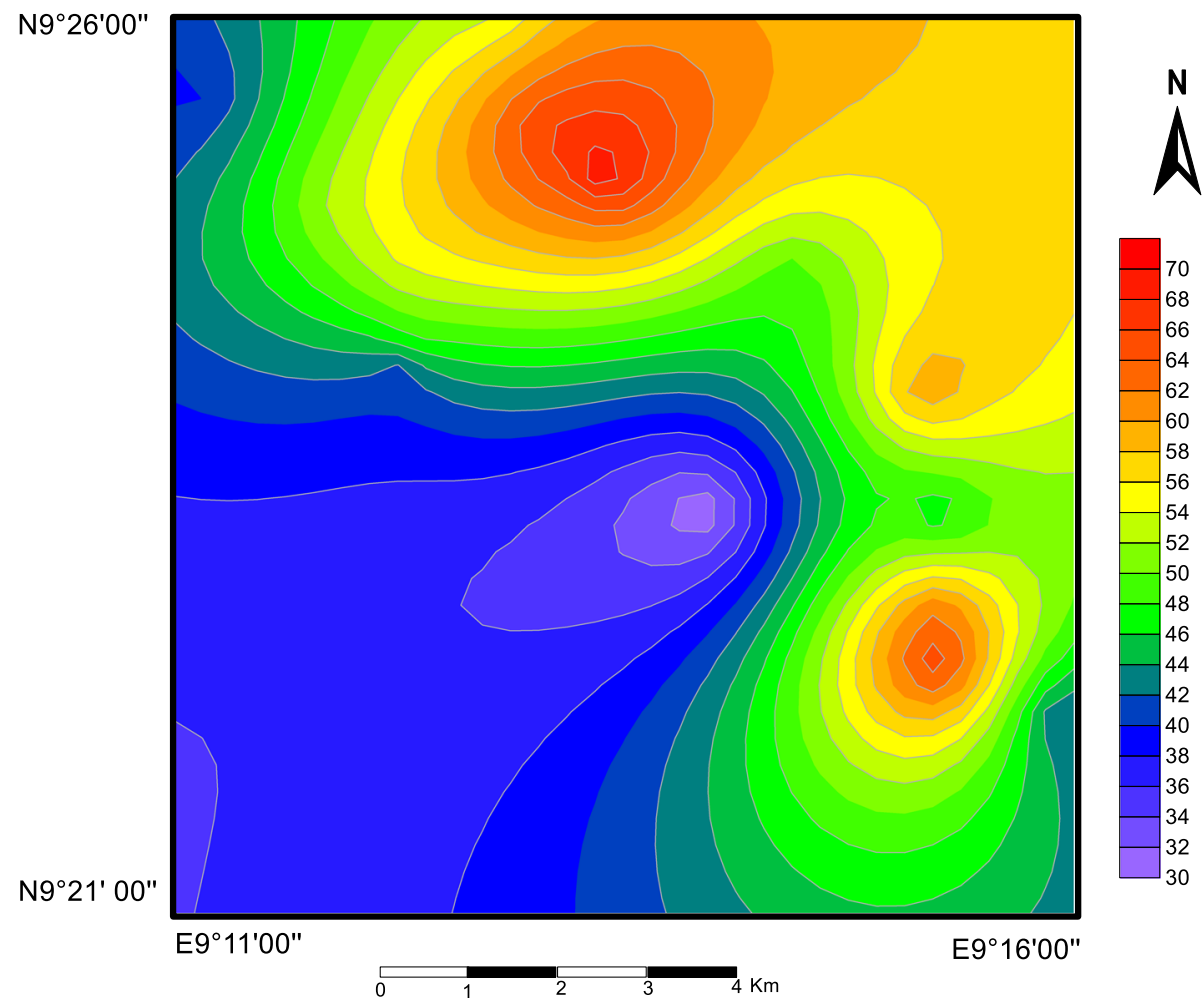

Fig. 7 Characterization of Liquid Limit in the area 
Table 3 Expansive soil classification based on plasticity index

\begin{tabular}{lll}
\hline Swell & \multicolumn{1}{l}{ Plasticity Index (\%) } & \\
\cline { 2 - 3 } Potential & Holtz and Gibbs (1956) & Chen (1988) \\
\hline Low & $<18$ & $0-15$ \\
Medium & $15-28$ & $10-35$ \\
High & $25-41$ & $20-55$ \\
Very High & $>35$ & $>35$ \\
\hline
\end{tabular}

The study looked at areas with low or no clay fraction mostly around the southern parts whereas at the northern parts, the soils have high clay fraction (Fig. 4a, b, c, and Fig. 5a and b) which is susceptible to swelling.

The Fig. 4b below characterize soils of the area on the basis of its clay content. The brownish colour represents areas with high percentage of clay fraction thereby, having high tendency to swell. The colourless or whitish parts are areas with moderate clay fraction and areas with blue colour are those with cohesionless i.e. soils with less or no clay fraction and that which can be described to be competent for the location of infrastructures as it relates to geotechnical studies.
Structural collapse in the area was studied in detailed revealing the type and causes of such collapse (Fig. 6) that has led to loss of millions of naira, thereby affecting the economy of not only the state but the country at large.

The samples, after analysis, presented a broad range of variation in their geotechnical properties. The liquid limit (LL), the plastic limit (PL), plasticity index, optimum moisture content (OMC), maximum dry density (MDD) and FSI values of samples in the area range from 30\% $76 \%, 20 \%-46 \%$, $10 \%$ to $25 \%, 13.8 \%-32.5 \%, 1.40-1.84$ $\left(\mathrm{g} / \mathrm{m}^{3}\right)$ and $9.1 \%-85 \%$ respectively (Table 1$)$.

The major parameters used to predict swelling of soils in the area were FSI, LL and PI. The liquid limit and plasticity index were both indirect methods while the FSI was a direct method employed in the determination of swelling potentials of soils as established by some authors.

\section{Liquid limit (LL)}

The liquid limit as a basis for predicting swelling in soils has been described by many authors. LL of soils is considered the water retention of that particular soil, which can be taken as a measure of soil swell - shrink behaviour. Chen (1965) and Snethen et al. (1977) have different standards in detecting soil swelling from LL

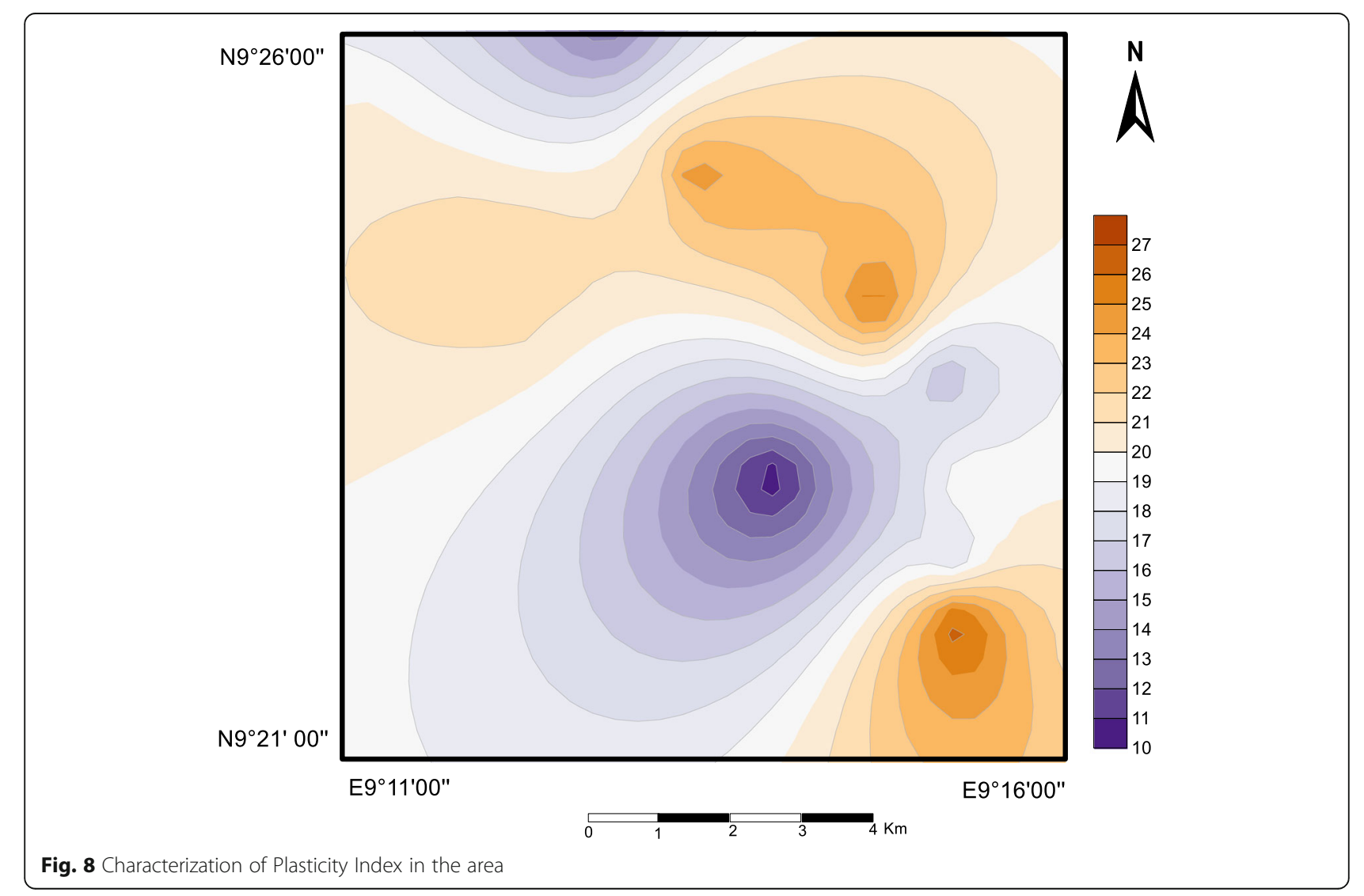


Table 4 Expansive soil classification based on FSI

\begin{tabular}{ll}
\hline Degree of Expansion & FSI \\
\hline Low & $<50$ \\
Medium & $50-100$ \\
High & $100-200$ \\
Very High & $>200$ \\
\hline
\end{tabular}

Bureau of Indian Standards 1987

(Table 2). Chen had a lower limit of $<30 \%$, intermediate/marginal limit of $30-40 \%$, high limit of $40-60 \%$ and very high limit of $>60 \%$ while Snethan had $<50$ as the lower limit, 50-60\% as the marginal/intermediate limit and $>60 \%$ as high. Samples analyzed from the area with lower LL according to Snethen et al. (1977) classification are; UAA $2,3,4,9,11,17,29,33,35$. Those that fall under the marginal category are samples UAA 26, 27 and 36 with LL between 50 and $60 \%$ are; the high category with LL > 60\% samples are UAA 14, 15, 16, 28, 30 and 34 and all these are reflected in areas shown in Fig. 7 below. Soils of the area have LL that ranged from 30 to $70 \%$. Areas with high LL are mostly located at the extreme north - central of the area (Fig. 7) where Panyam is located. The south - western parts of the area has soils with LL that are classified low in terms of swell potential and these are mostly located at Kwa, Niyes and Kopal.

\section{Plasticity index (PI)}

Plasticity Index of soils in the area was an indirect method to predict swelling. Holtz and Gibbs (1956) and Chen (1988) used PI to predict swelling. Holtz and Gibbs categorized soils with PI $<18$ as low, 15-28 as a medium, 2541 as high and > 35 as very high. Chen categorized soils with PI as follows; 0-15 as low, 10-35 as medium, 20-55 as high and > 35 as very high. Samples characterized as having low swell potential due to low PI are UAA 4, 6, 9 and 35; those with medium swell potentials are UAA 3, 5, $14,24,25,26,27,29,30,31,33,34$ and 36 according to Chen (1988) (Table 3). The PI values of soils of the area revealed a range of $10-27 \%$. The dominant samples have intermediate PI according to both authors quoted as falling in the intermediate category and dominantly located around Panyam and environs (Fig. 8).

\section{Free swell index}

The FSI is the direct method that was used to measure swell potentials of soils. It is one of the most effective methods that are being used to determine soil

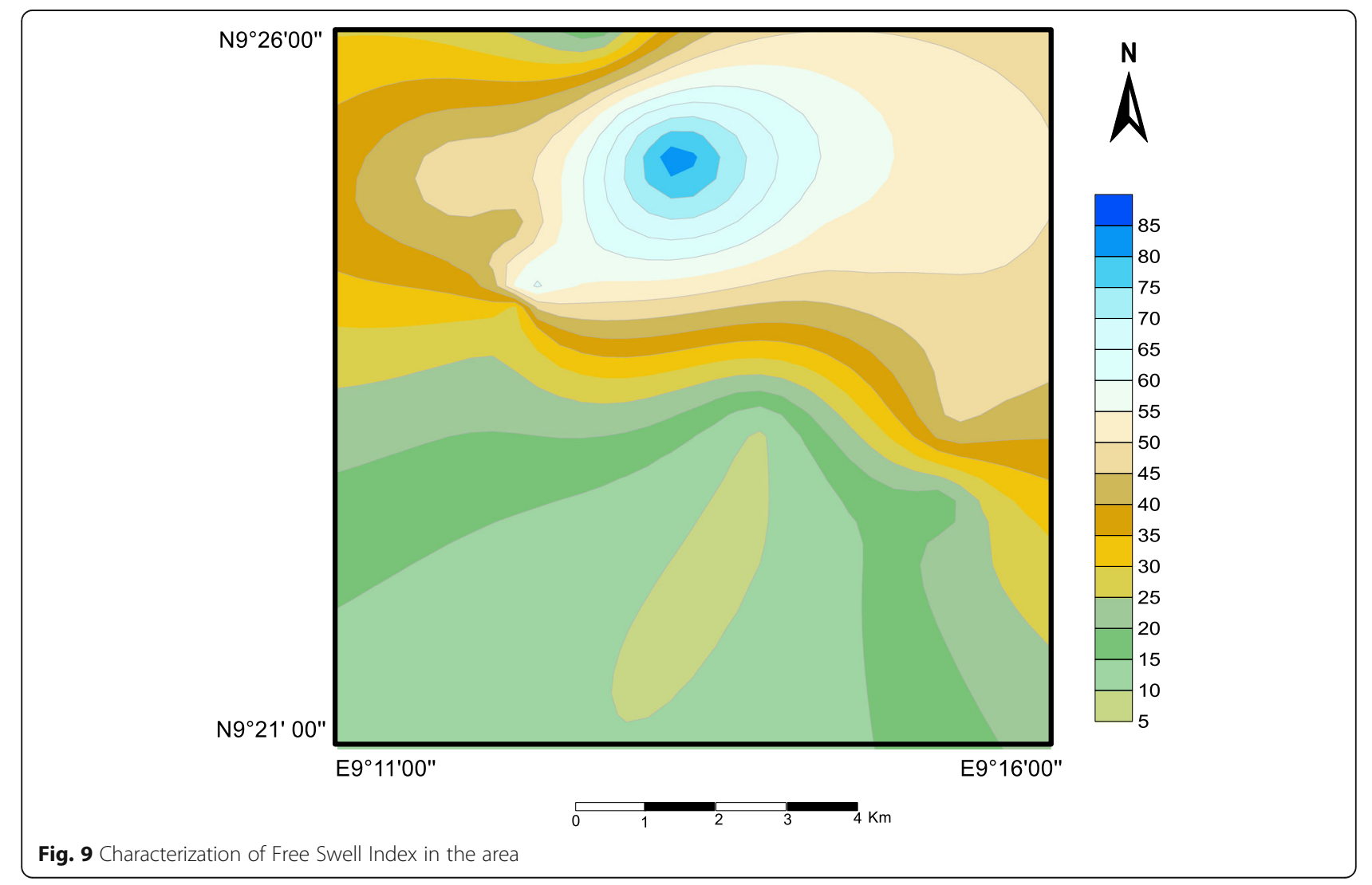


swell behaviour. The method is more useful compared to the indirect methods discussed above. According to the Bureau of Indian Standards (1987), soils were characterized according to their swell potential as low, medium, high and very high with corresponding FSI values as $<50 \%, 50-100 \%, 100-200 \%,>200 \%$ respectively (Table 4).

From the above characterization, samples UAA 3, 4, 5, $6,9,24,25,26,27,29,33,35$, and 36 have low degree of expansion; samples UAA 14, 15, 16, 28, 30, 31 and 34 have medium degree of expansion. All samples falling under the medium degree of swelling are located around Panyam area also at the north-central parts of the study area (Fig. 9).

The structural analysis looked at both the surface and sub-surface structures. The surface structures involve supplanting the aeromagnetic analysis by way of directly mapping structures on outcrops.

Joints occur in most of the rock types although very pronounced in the granitic gneiss (Plate 2). The joints in the area are both closed and opened. The joints spacing was within the range of a few

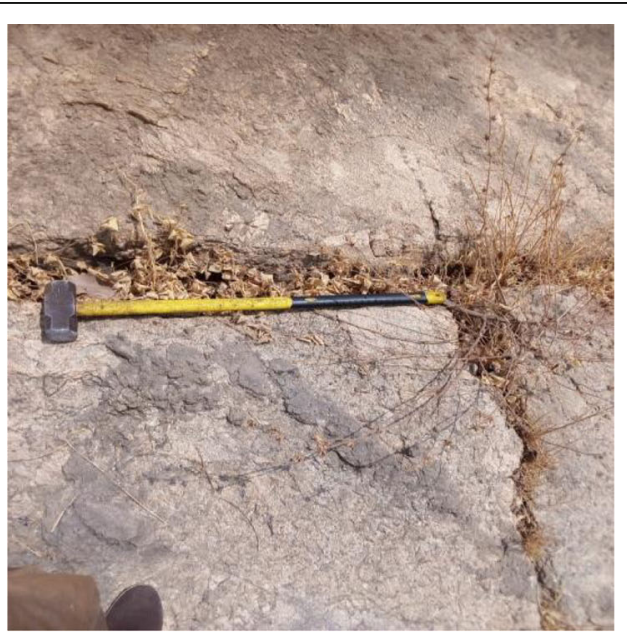

$\mathrm{a}:$

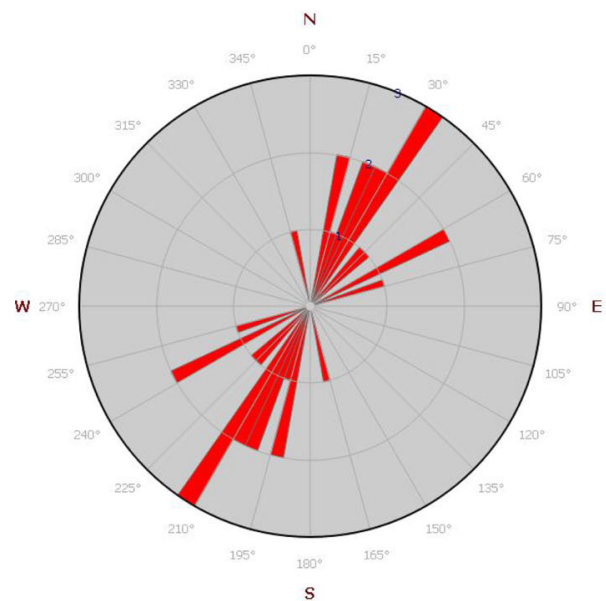

a Biotite muscovite granite

no. of data $=126$

dominant trends $=\mathrm{NNE}-\mathrm{SSW}$

minor trends $=$ ENE - WSW

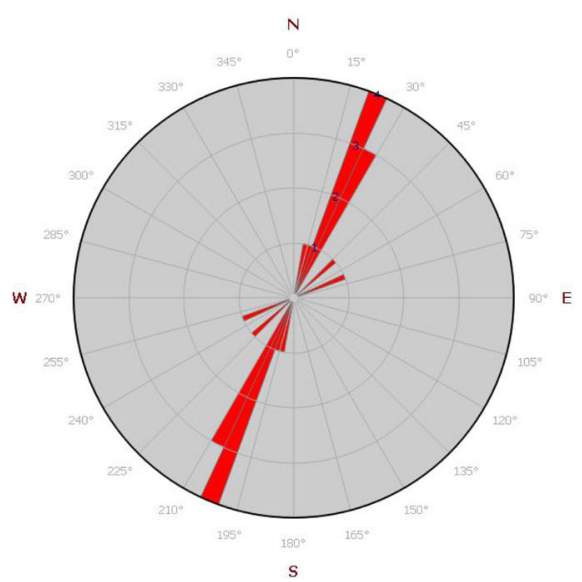

b granitic gneiss

no. of data $=201$

dominant trends $=\mathrm{NNE}-\mathrm{SSW}$

minor trends $=$

b:

Fig. 10 a Photograph of Joints on granitic gneiss of the area. b Rose plot of joints on granitic gneiss and muscovite granite of the area 


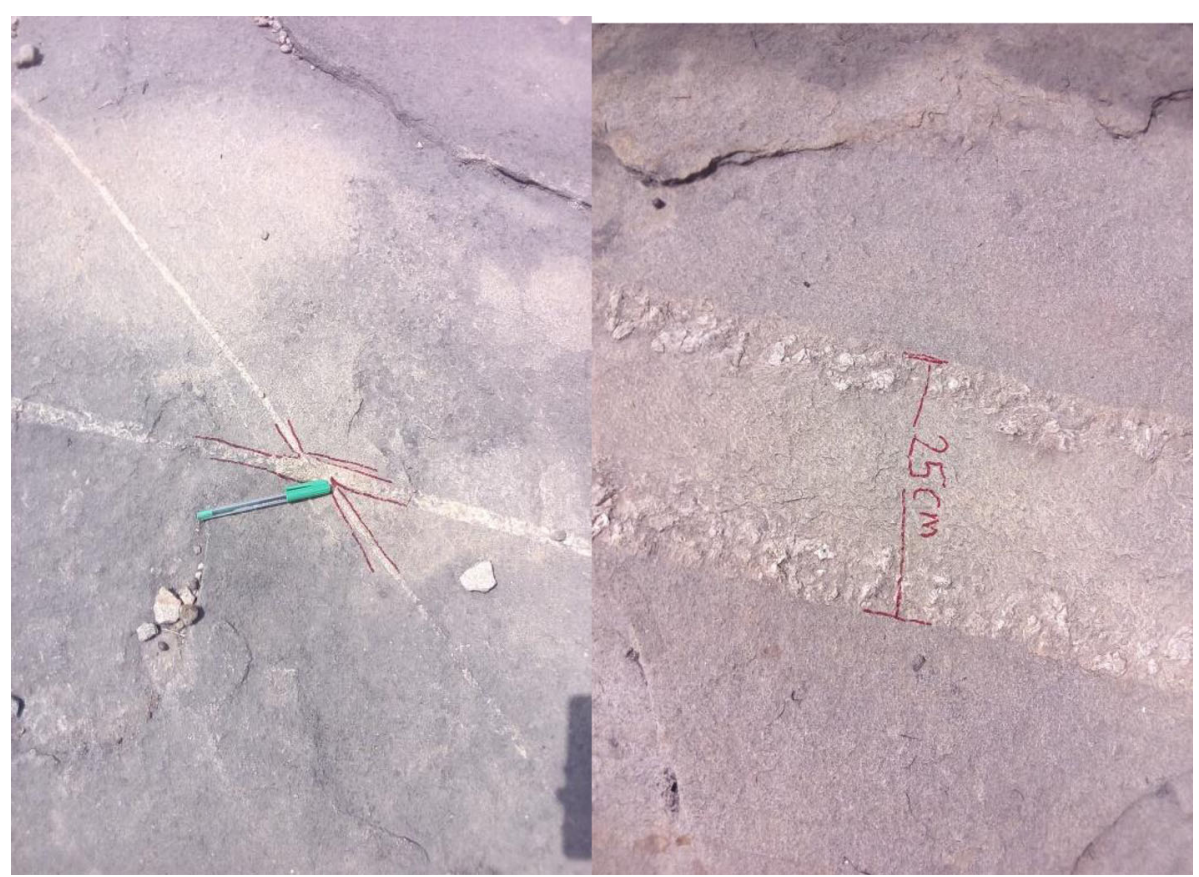

a.

b.

Fig. 11 Photograph of veins on biotite muscovite granite and granitic gneiss. a Biotite muscovite granite. $\mathbf{b}$ Granitic gneiss

millimetres to $5 \mathrm{~cm}$ in areas where they occur as a joint set. In some exposures, they crosscut the rocks both horizontally and vertically. Field evidence shows that the rocks have more than one generation of joints. Joint values plotted on a rose diagram shows that the principal joints direction in the area is in the NNW-SSE direction (Fig. 10).

A vein is a distinct sheet-like body of crystallized minerals cross-cutting a rock. Veins are formed when mineral constituents carried by an aqueous solution

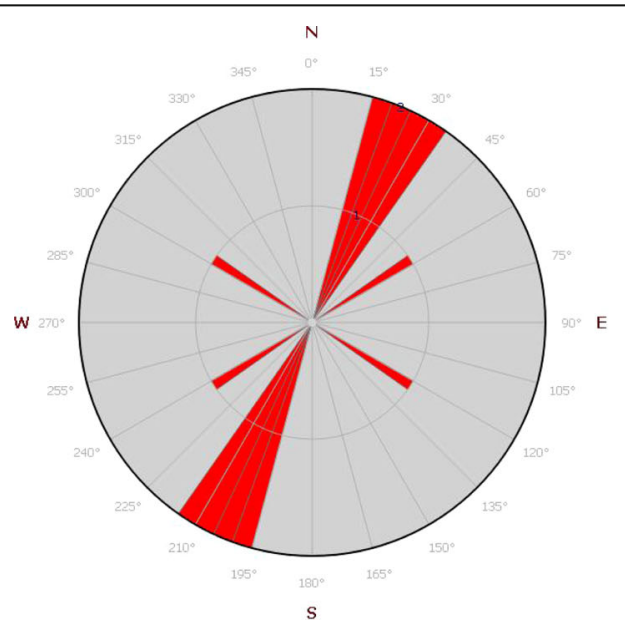

a

no. of data $=42$

dominant trends $=\mathrm{NNE}-\mathrm{SSW}$

minor trends $=\mathrm{ENE}-\mathrm{WSW}$ and WNW -ESE

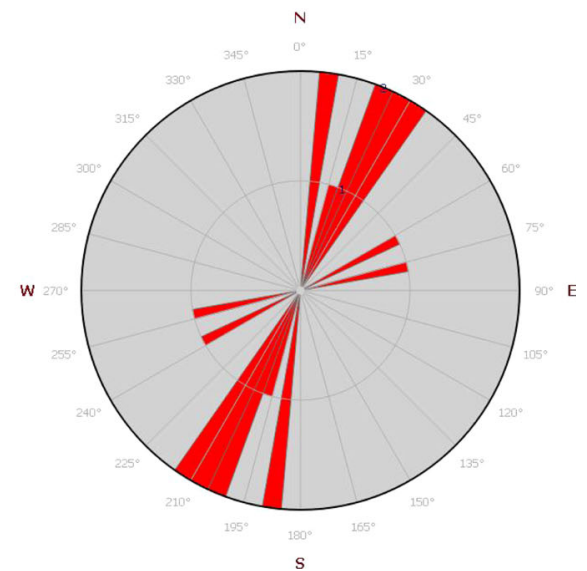

b

no. of data $=65$

dominant trends $=\mathrm{NNE}-\mathrm{SSW}$

minor trends $=\mathrm{ENE}-\mathrm{WSW}$

Fig. 12 Rose plot of veins on granitic gneiss and muscovite granite of the area. a Biotite muscovite granite. $\mathbf{b}$ Granitic gneiss 
within the rock mass are deposited through precipitation. They are usually emplaced during or after the formation of the original host/country rock. Veins in the area whose names were based on the mineralogical composition are quartz, quartzo-feldspathic veins, pegmatitic veins, etc. The extent of the veins depends on the size of the exposure. Quartz and quartzo-feldspathic veins (Fig. 11) range from $1 \mathrm{~m} \mathrm{-}$ $3 \mathrm{~m}$ in length and few millimeters to $20 \mathrm{~cm}$ wide. The quartz veins composed completely of quartz crystals while quartzo-feldspathic veins have both quartz and feldspar crystals. The Rosette diagram of veins also indicates an orientation trending in an NNE-SSW direction (Fig. 12) in compliance with that of foliation in the area. In some places, the veins intersect each other resulting in the crosscutting relationship which enables one to determine their order of formation.

The rose plots of structures in the area showed dominant trends in the NNE - SSW direction agreeing with the surface mapping and earlier trend direction indicated.

To complement direct measurements of fractures on the field, landsat image of the area was acquired from the Nigerian Geological Survey Agency (NGSA) for processing to bring out the lineament density and also the orientation of fractures in the area. The composite map of the area (RGB 742) was processed to bring out the lineament of the area as presented in (Fig. 13 and Fig. 14).
Also, vertical electrical soundings (VES) of some nine points within the area were conducted revealing the geo-electric profiles and also the thickness of such layer in the profile were the soil is cohesive in nature (Fig. 15, Table 5). VES (1-4) points were taken around Nyes and environs indicative of cohesionless (non-swelling) soils while VES (5-9) points were taken around Panyam, Duglon and environs whose soils are cohesive (swelling) (Fig. 16).

This work entails using more than two equivalent source layers and bandpass filtering to provide a better overall fit to the spectrum of the observed data and better control on anomaly separation from the total magnetic intensity map of the area (Fig. 17).

The modified reduced to pole (mRTP-TMI) anomaly map was used in the qualitative interpretation, instead of the original TMI anomaly map, because the effects of the geomagnetic inclination on the shape of the magnetic anomalies have been removed such that the peaks of anomalies occur directly above their respective causative geological bodies (Fig. 18).

The power spectra model was generated automatically using matched filtering method to separate the different layers for the analysis. The generated spectra were fitted with four equivalent magnetic source layers which were later used to slice the mRTP-TMI anomaly map into four different depths (Table 6 Figs. 19 and 20).

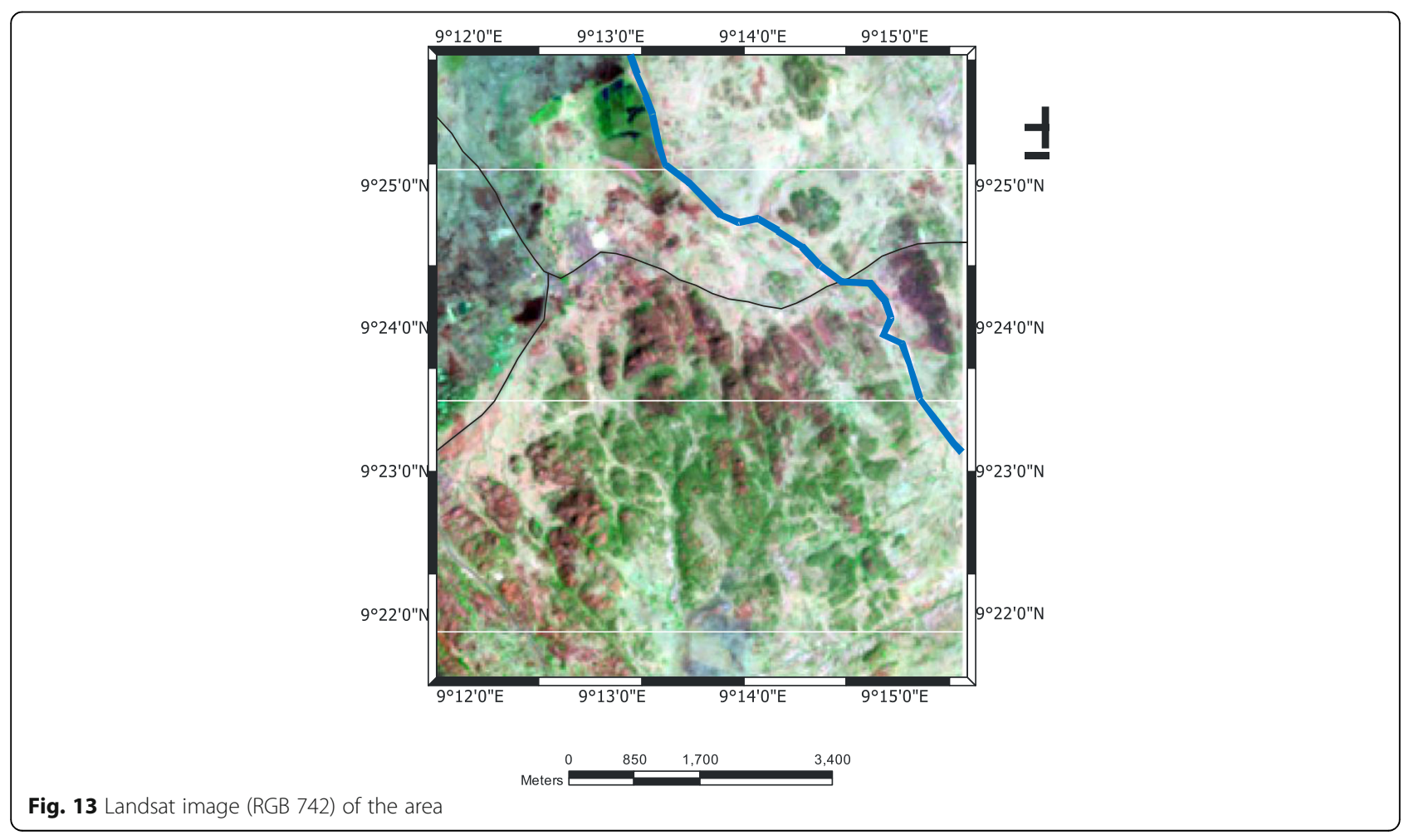




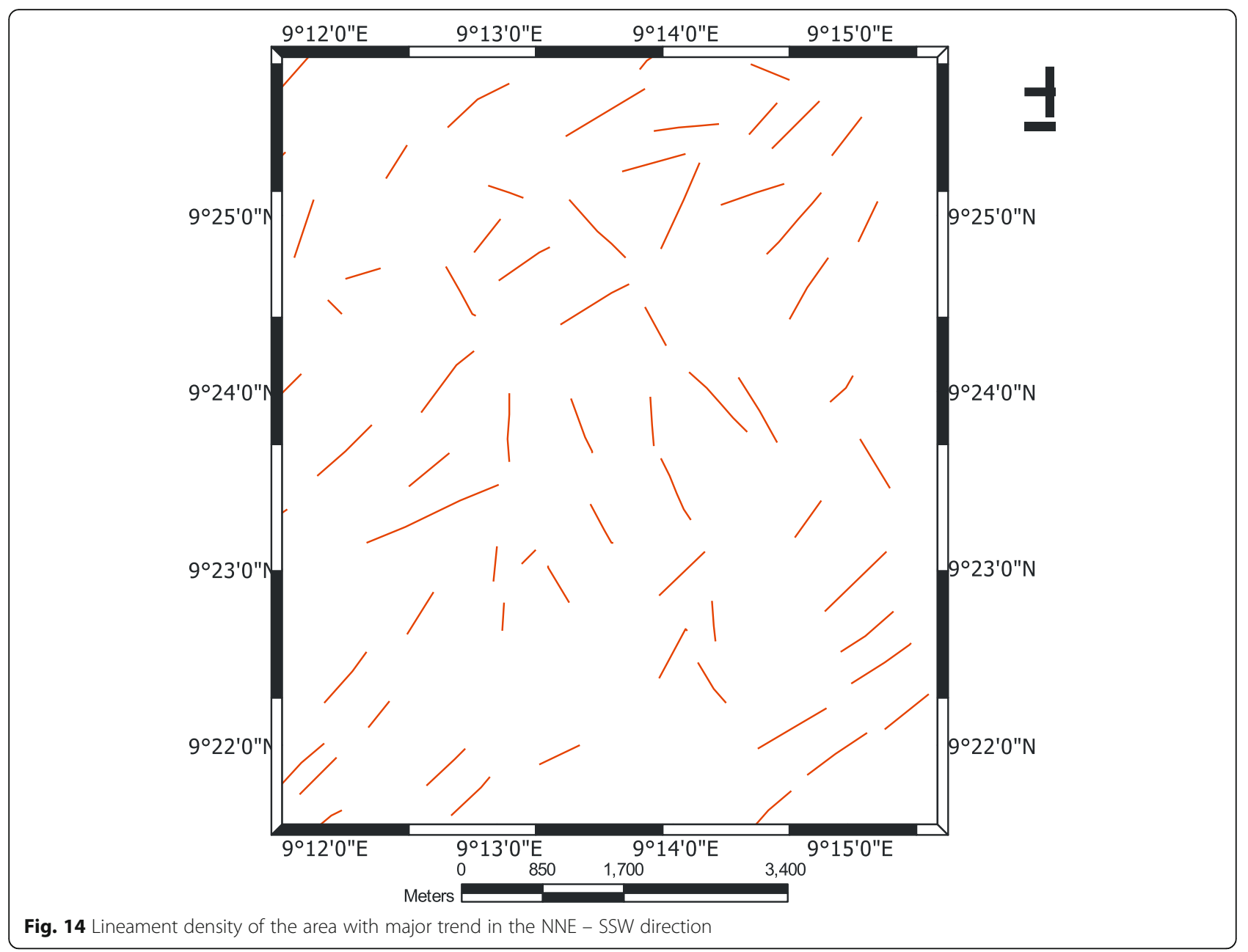

The different depth sliced layers as in Fig. 19 (3, 2, 1, 0), have different bandpass wavelengths with depth at $42 \mathrm{~m}$, $426 \mathrm{~m}, 1147 \mathrm{~m}$ and $5423 \mathrm{~m}$ respectively indicating an increase in depth from layer 3 to layer 0 .

Generally, the structural and tectonic processes may influence the magnetic response of geological units. For example, fault zones or fractured zones show normally low intensity. This can be due to the passing of water or some weathered minerals. The shape of these anomalies is generally visible as linear structures. But in the case where magnetic minerals are formed, such structures would show linear magnetic anomalies with high density.

Total horizontal derivative (THD) (an important edge enhancement method in the magnetic data processing) method was applied on layer 3 and layer 2 (Fig. 21a and b) to enhance the edges of linear and/or curvilinear features.

The resultant edge enhanced maps (Edge enhanced THD of layers 3 and 2) as presented in Fig. 22a and b and Fig. 23a and b. Common orientations of the linear/ curvilinear features (lineaments) are mainly NNE-SSW for layer 3 and NE-SW for the deeper layer 2 .

\section{Conclusions}

The samples, after analysis, presented a broad range of variation in their geotechnical properties. The result of the grain size analysis implies the significant presence of clay fraction which has the potential to swell. The indirect methods (LL and PI) that were used to determine the swelling potential of soils of the area characterized the soils as low to moderate in terms of swelling. Also, the direct method (FSI) which is the most effective geotechnical method used in characterizing soils of the area, falls under the low to medium swelling potential. It is therefore concluded that, from both the direct and indirect methods used, soils of the area generally fall under low to medium categorization in terms of swelling and as a result, the geotechnical parameters have a marginal effect on the collapse of infrastructure in areas where the soils are cohesive in nature. 


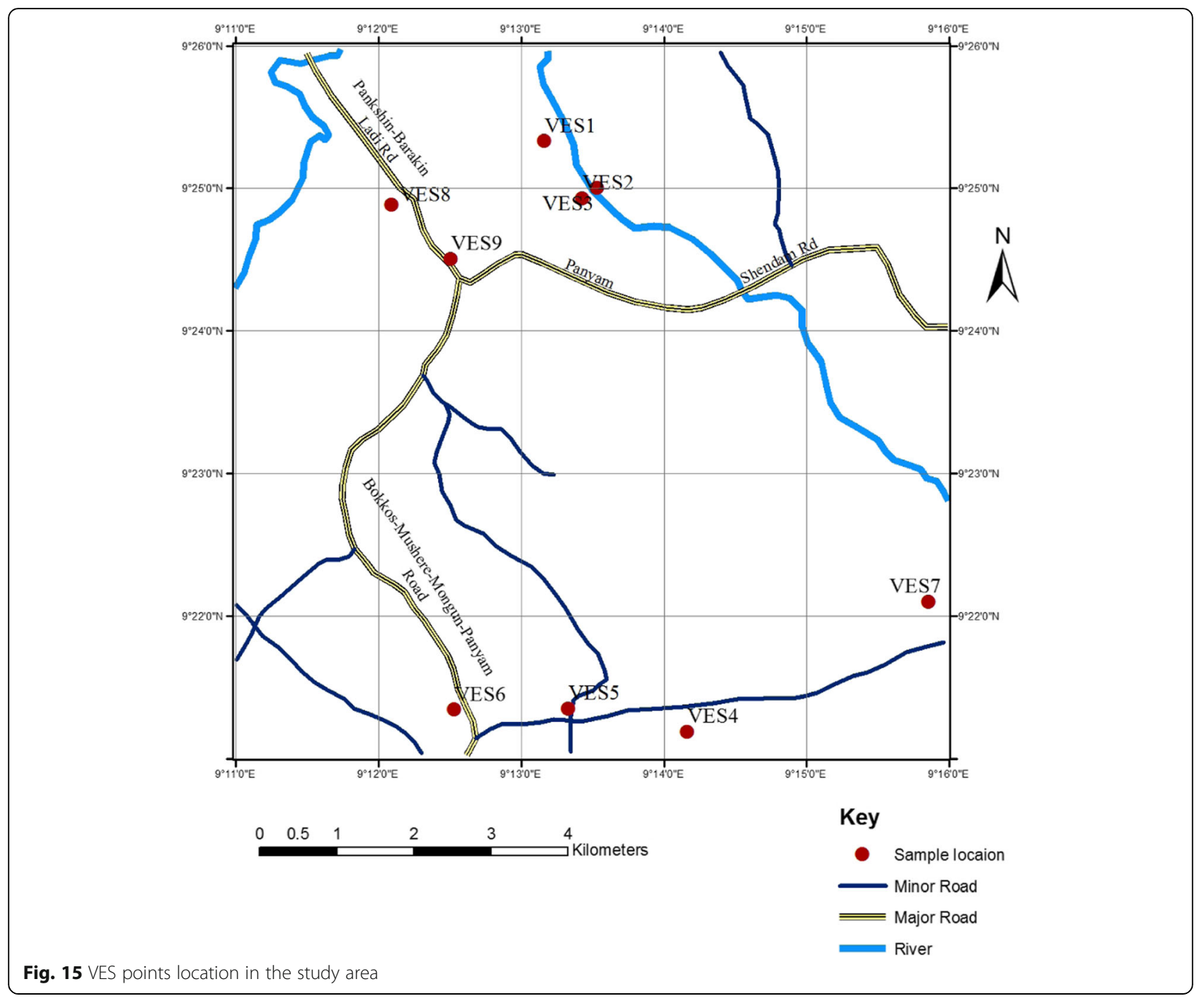

Lineament analysis is a valuable source of information for studying the structural setting of an area, it helps to reveal zones of fracture concentration and identification of surface features. Linear features as seen on satellite images are usually the results of aligned morphologic rock or topographic relief of the basement. The aeromagnetic and Landsat lineament maps of the study area have been summarized using rose diagrams, revealing NNE - SSW as the major trend with some secondary trends NW-SE, NNW - SSE and NE - SW directions. However, the NNE-SSW trend reflects lineament direction at $42 \mathrm{~m}$ corresponding to surface measurements while the NE - SW direction corresponds to the regional trend of layers 3 and 2 respectively. It was discovered during mapping that structures constructed across the major trend of fractures tend to be more stabilized as against those constructed along the major trend of fractures in some areas within the study area. This could be as a result of a deep-seated fault or the infilling of fractures by water.

It was observed from the study that both geotechnical (soil parameters) and structural analyses affected infrastructures that led to collapse or defects in the study area. The northern portion of the area where cohesive soils are dominant, the collapse/defects on infrastructures was directly related to the nature of soils in the area. The southern parts where the soils are cohesionless and competent also have infrastructures that have either collapsed or are showing defects as a result of the fractures measured in the area that were aligned in the NNE - SSW direction as agreed by field measurements, lineament studies from both surface and sub-surface as a result of infilling and subsequent expansion of such fractures either by water or other conditions leading to the expansion of the fractures. 
Table 5 Vertical Electrical Soundings (VES) of the different areas showing depth and thickness of soil layers

\begin{tabular}{|c|c|c|c|c|c|}
\hline VES & Layers & Resistivity (Ohm-m) & Thickness (m) & Depth (m) & Description \\
\hline \multirow[t]{3}{*}{1} & 1 & 861 & 2.15 & 2.15 & Top soil/Laterite \\
\hline & 2 & 126 & 1.93 & 4.08 & Weathered Regoliths \\
\hline & 3 & 290,000 & $\infty$ & $\infty$ & Basement \\
\hline \multirow[t]{3}{*}{2} & 1 & 321 & 1.538 & 1.538 & Top soil/Laterite \\
\hline & 2 & 3527 & 4.105 & 5.643 & Fractured layer \\
\hline & 3 & 15,953 & $\infty$ & $\infty$ & Crystalline Basement \\
\hline \multirow[t]{3}{*}{3} & 1 & 1181 & 2.965 & 2.965 & Top soil/Laterite \\
\hline & 2 & 175.6 & 3.451 & 6.416 & Weathered Regoliths \\
\hline & 3 & 2026 & $\infty$ & $\infty$ & Basement \\
\hline \multirow[t]{3}{*}{4} & 1 & 1572 & 2.281 & 2.281 & Top soil/Laterite \\
\hline & 2 & 166.3 & 1.6972 & 4.254 & Weathered Regoliths \\
\hline & 3 & 1329 & $\infty$ & $\infty$ & Basement \\
\hline \multirow[t]{3}{*}{5} & 1 & 1112 & 0.2943 & 0.2943 & Top soil/Laterite \\
\hline & 2 & 365.1 & 3.258 & 3.553 & Weathered Regoliths \\
\hline & 3 & 3047 & $\infty$ & $\infty$ & Crystalline Basement \\
\hline \multirow[t]{5}{*}{6} & 1 & 23.2 & 1.4 & 1.4 & Top soil/ laterite \\
\hline & 2 & 11 & 4.64 & 4.64 & Clayey laterite \\
\hline & 3 & 170 & 0.98 & 7.02 & Weathered layer \\
\hline & 4 & 11,799 & 16.9 & 23.9 & Crystalline Basement \\
\hline & 5 & 676 & Infinity & Infinity & Fractured layer \\
\hline \multirow[t]{5}{*}{7} & 1 & 28.4 & 1.73 & 1.73 & Top soil/ laterite \\
\hline & 2 & 6.63 & 1.94 & 3.66 & Clayey laterite \\
\hline & 3 & 281 & 1.5 & 5.17 & Weathered layer \\
\hline & 4 & 90,705 & 0.67 & 5.83 & Crystalline Basement \\
\hline & 5 & 59.4 & Infinity & Infinity & Fractured layer \\
\hline \multirow[t]{5}{*}{8} & 1 & 2.58 & 1.12 & 1.12 & Clayey laterite \\
\hline & 2 & 34.5 & 3.29 & 4.40 & Laterite \\
\hline & 3 & 10,957 & 2.09 & 6.05 & Crystalline Basement \\
\hline & 4 & 395 & 43.5 & 50.00 & Fractured layer \\
\hline & 5 & 554 & Infinity & Infinity & Fractured layer \\
\hline \multirow[t]{6}{*}{9} & 1 & 328 & 1.16 & 1.16 & Top soil \\
\hline & 2 & 37.22 & 6.27 & 7.43 & Weathered layer \\
\hline & 3 & 503 & 1.46 & 8.89 & Fractured layer \\
\hline & 4 & 10,491 & 15.04 & 23.92 & Hard Basement \\
\hline & 5 & 12,518 & 26.08 & 50.00 & Fresh basement \\
\hline & 6 & 16,554 & Infinity & Infinity & Fresh basement \\
\hline
\end{tabular}




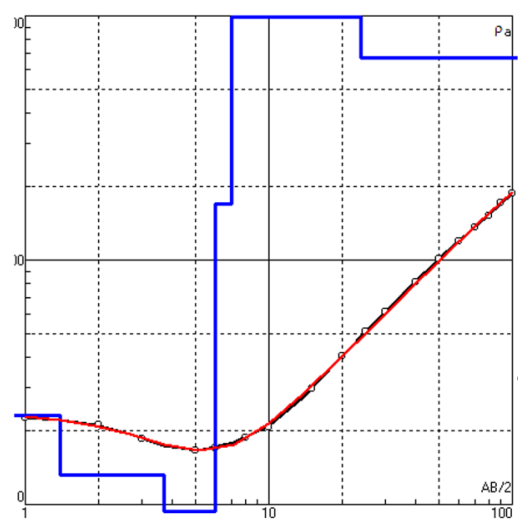

a

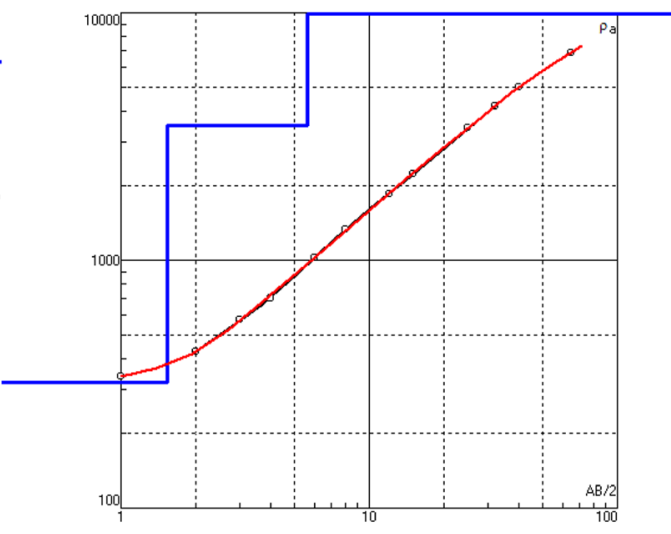

b

Fig. 16 Selected VES curves for (a) cohesive soils (b) for cohesionless soils

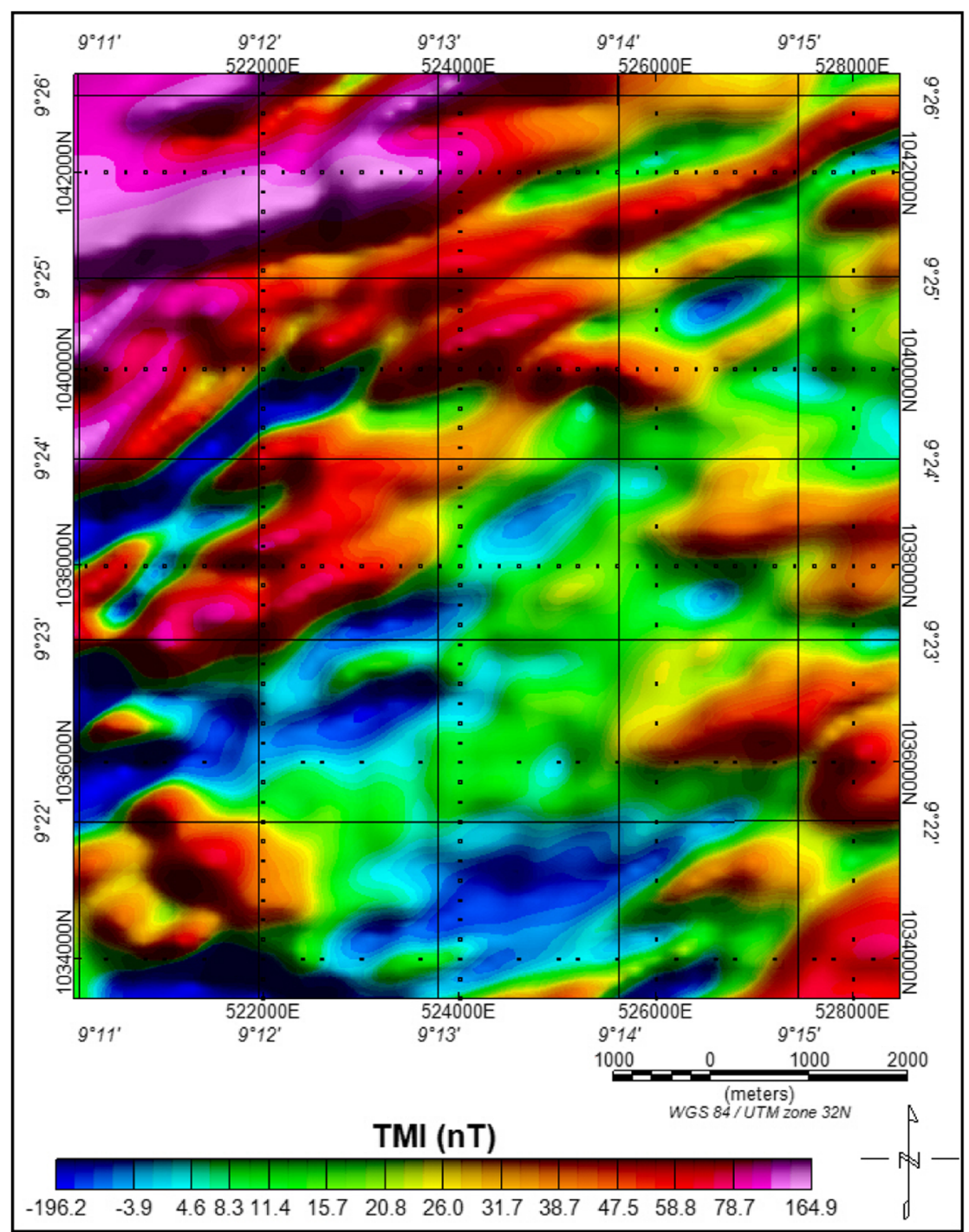

Fig. 17 TMI (Total Magnetic Intensity) anomaly map of the study area 


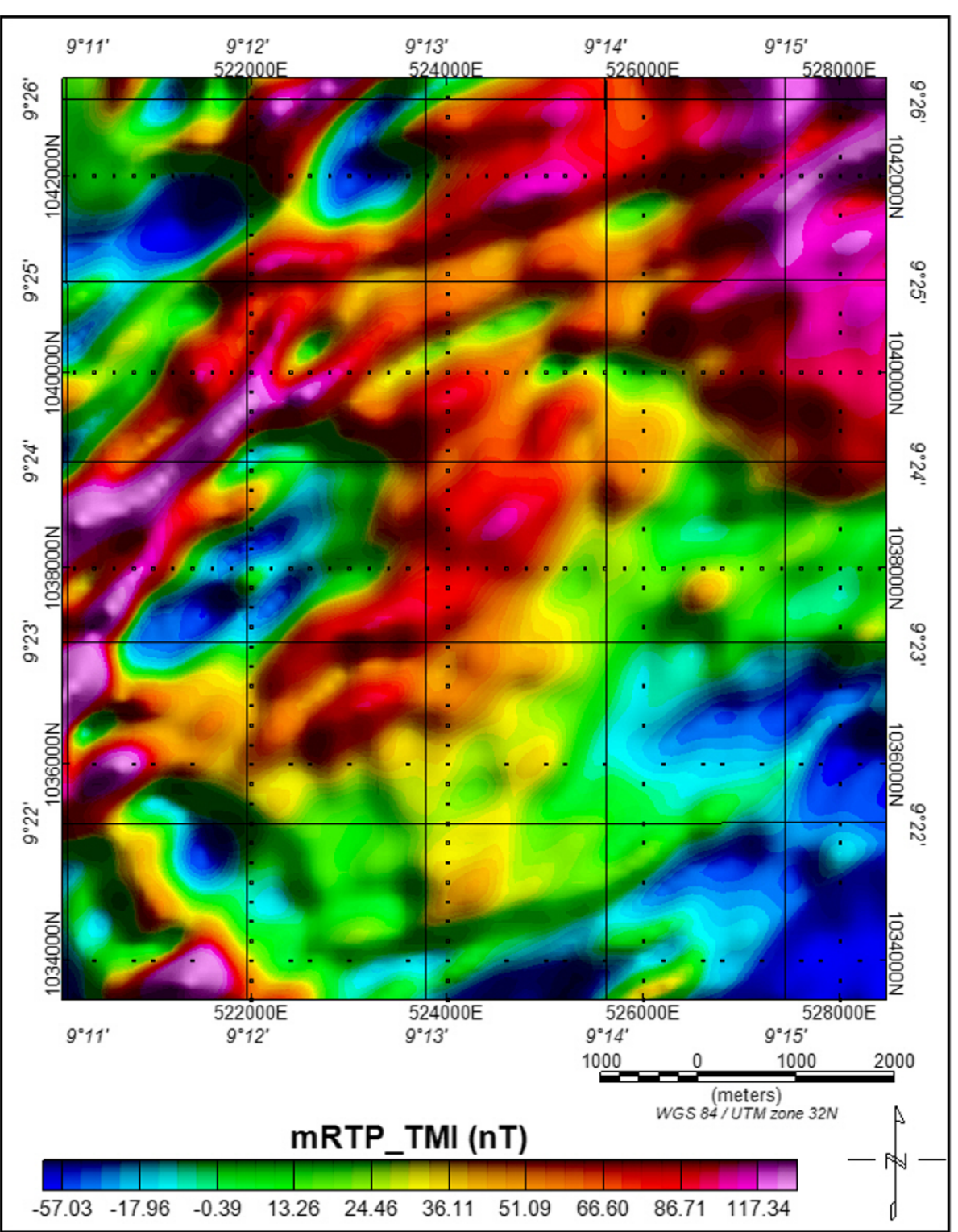

Fig. 18 Modified reduced to pole magnetic anomaly map

Table 6 different layers of the Earth with depth

\begin{tabular}{lr}
\hline Layer & Depth $(\mathrm{m})$ \\
\hline 3 & 42.14 \\
2 & 426.96 \\
1 & 1147.97 \\
0 & 5423.56 \\
\hline
\end{tabular}




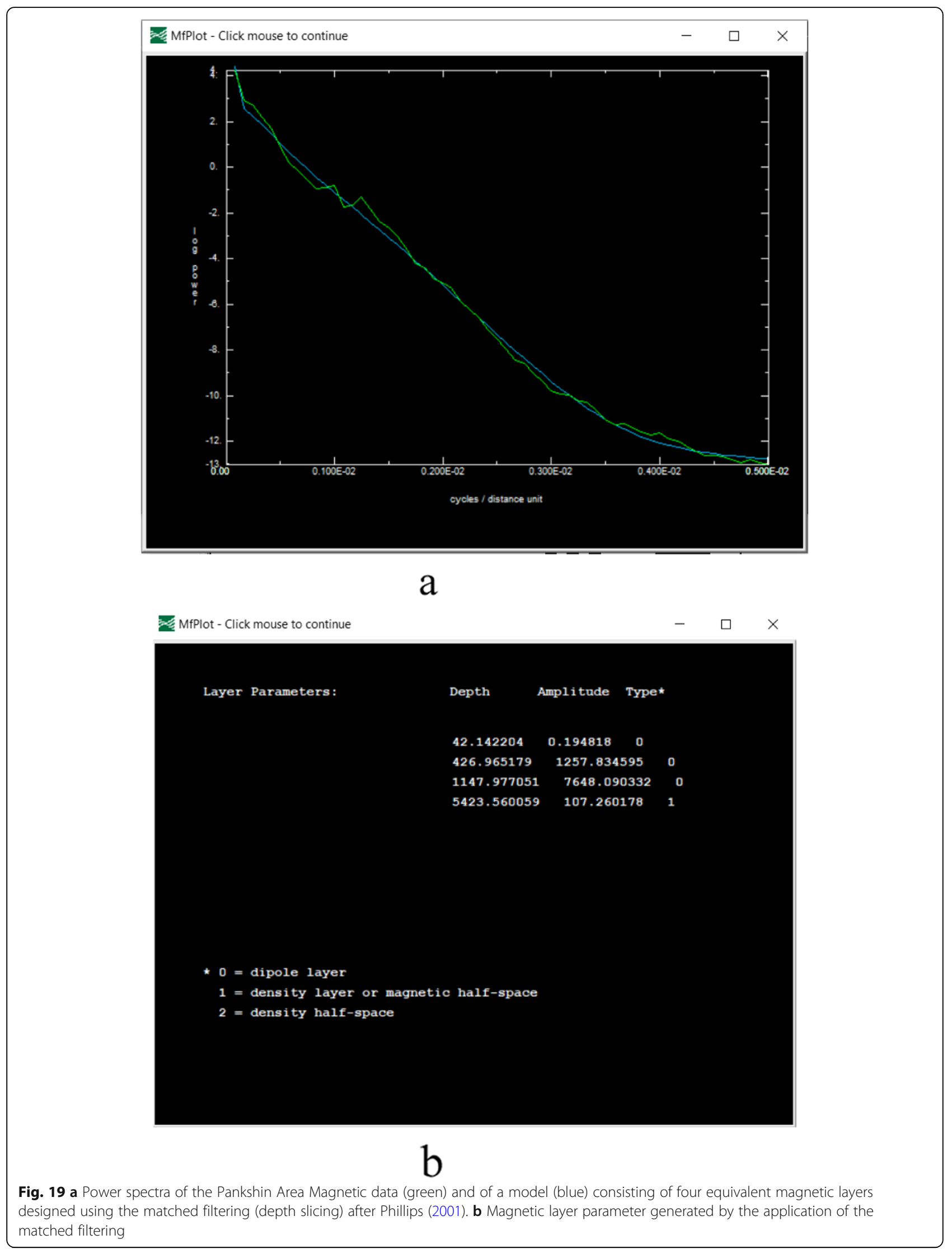




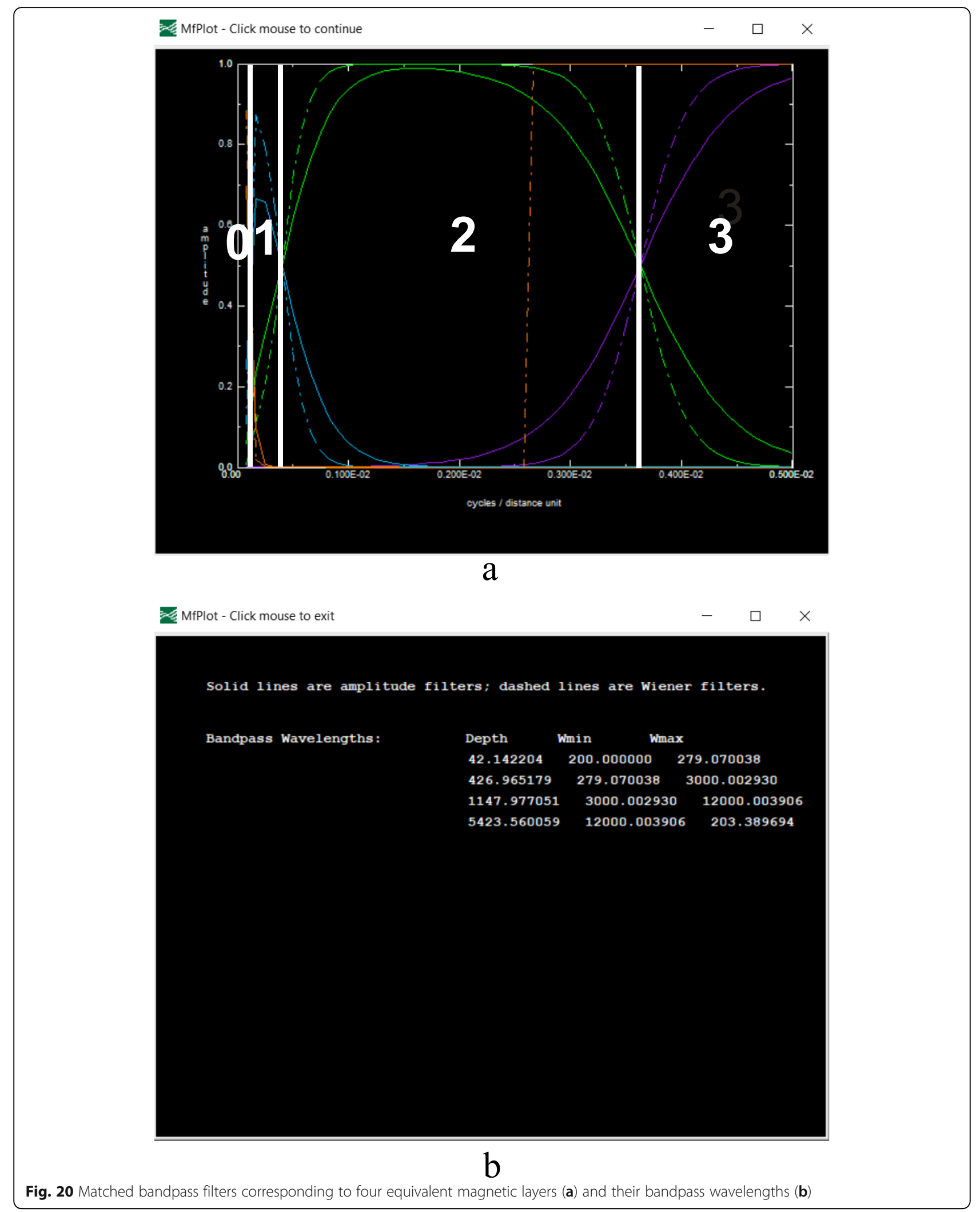




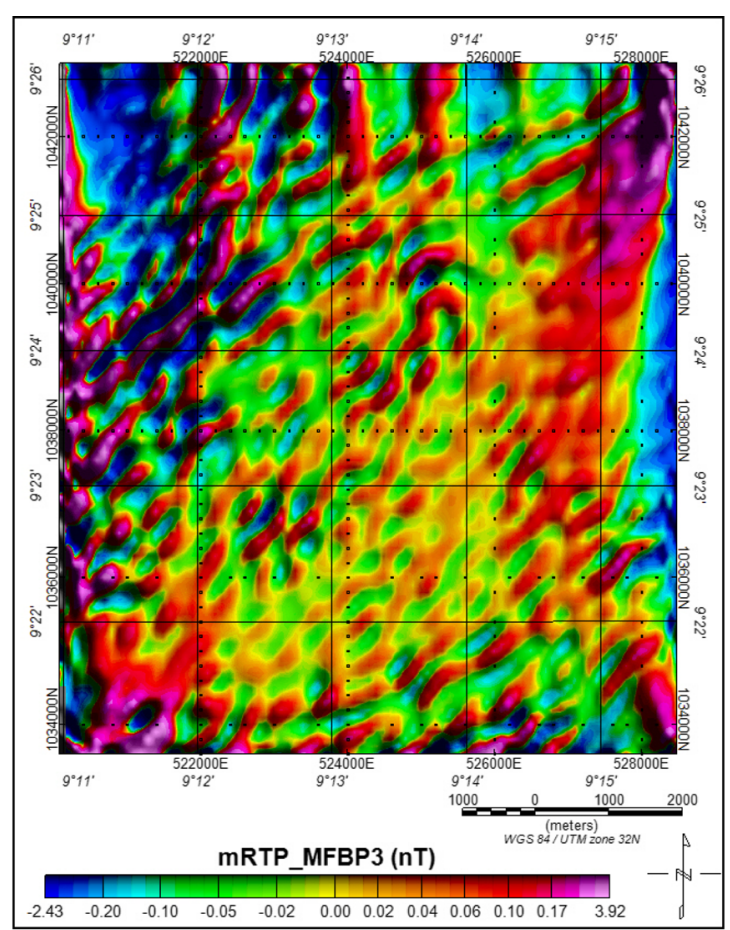

a:

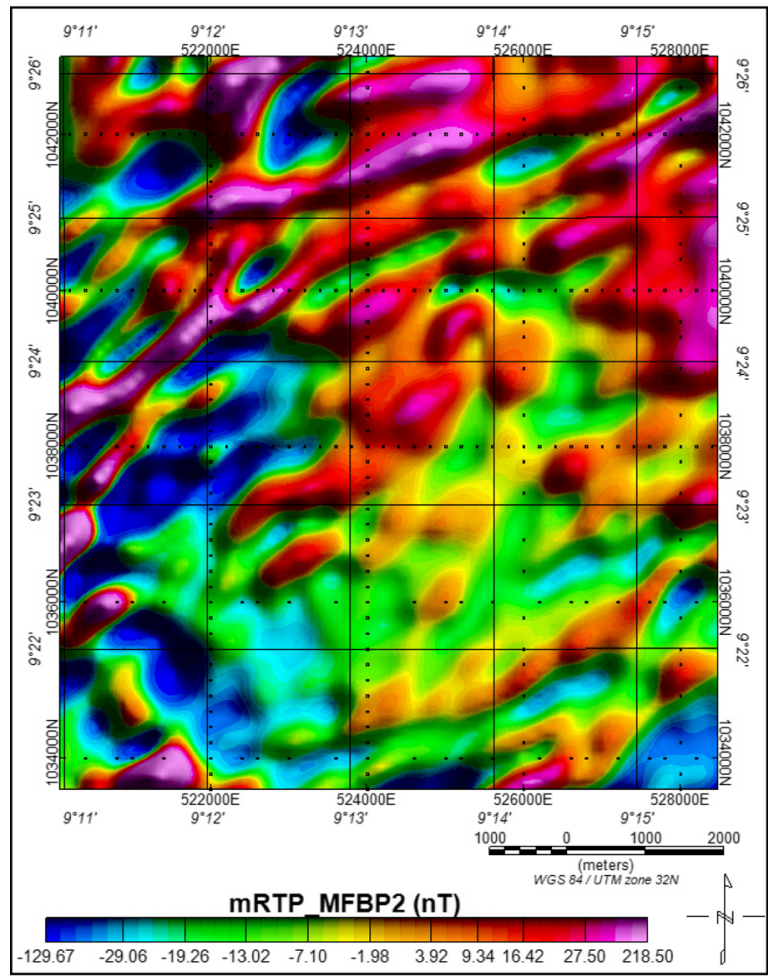

b:

Fig. 21 a Matched Filtering Bandpass of layer 3. b Matched filtering Bandpass of layer 2 


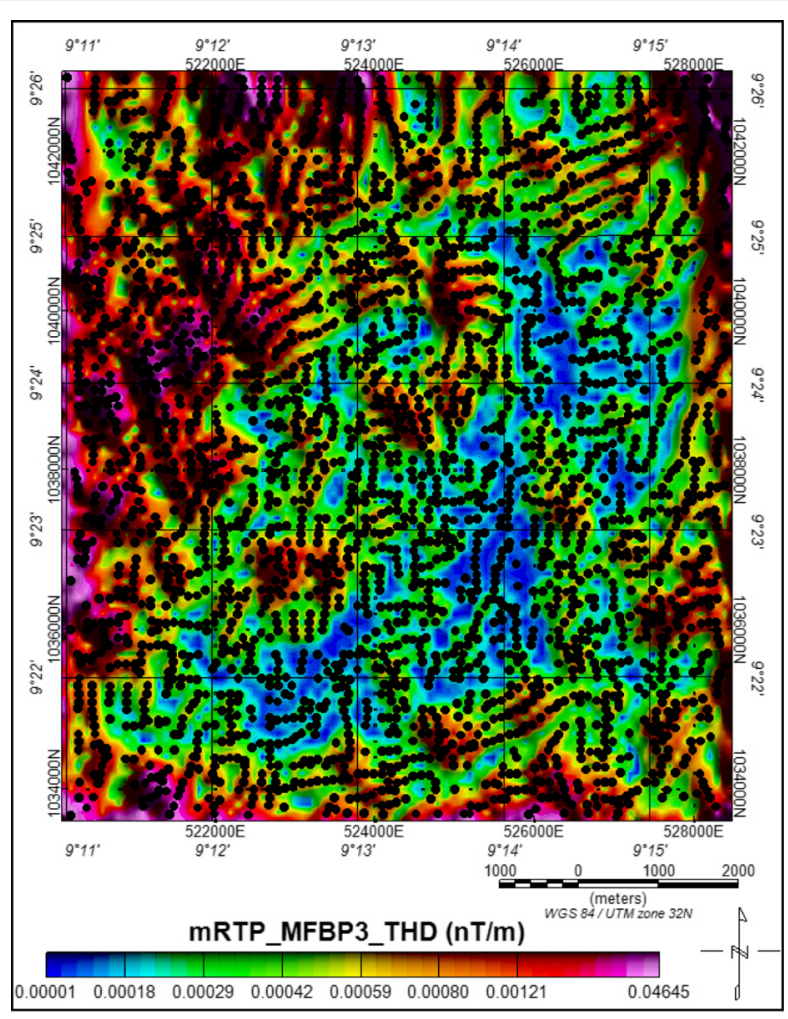

$\mathrm{a}:$

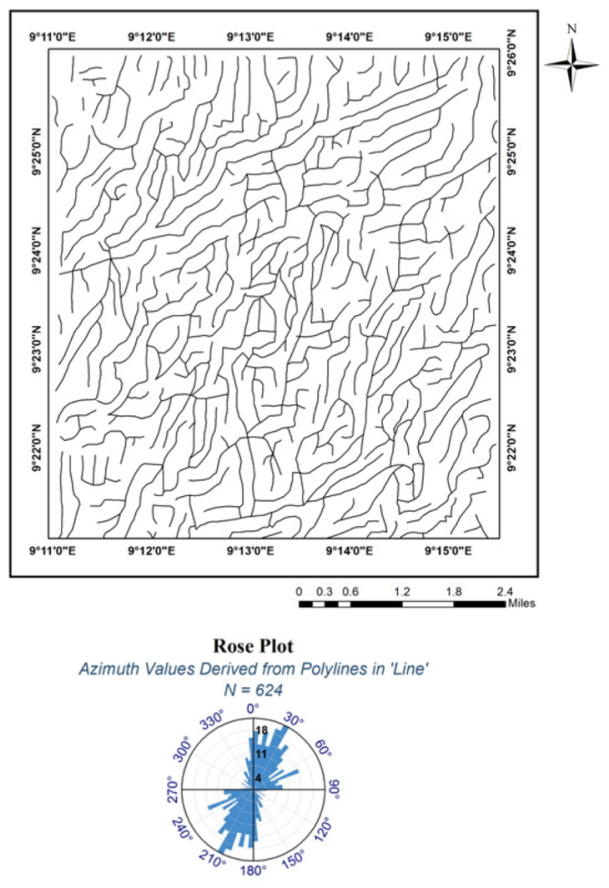

b:

Fig. 22 a Edge enhanced total horizontal derivative of layer 3. b Linear/curvilinear map of layer 3 


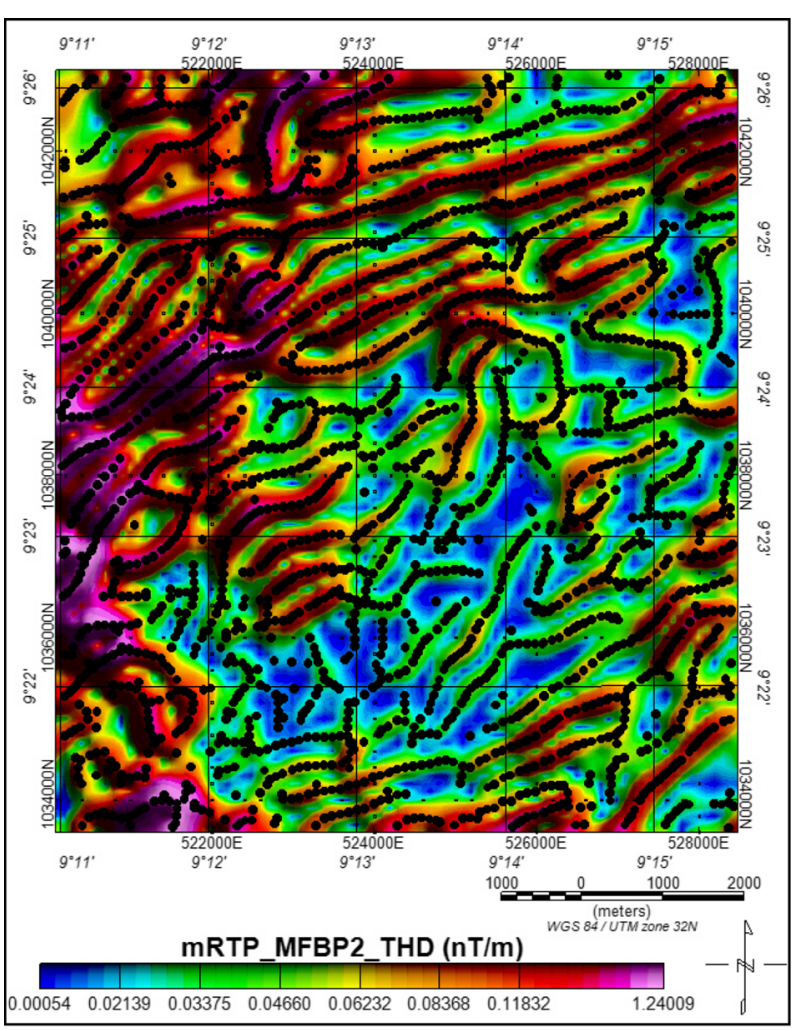

a:

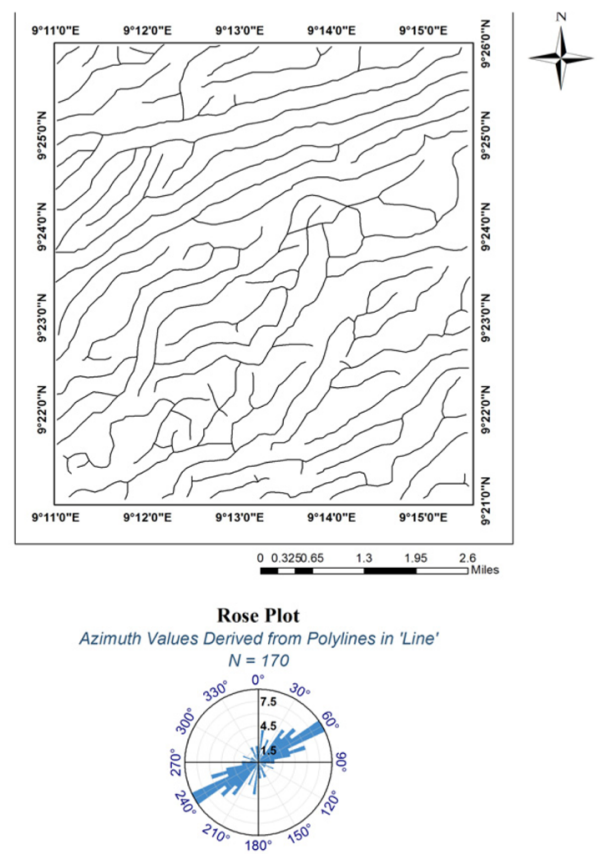

b:

Fig. 23 a Edge enhanced total horizontal derivative of layer 2. b Linear/curvilinear map of layer 2 


\section{Acknowledgements}

Not applicable.

\section{Authors' contributions}

The first Author participated in the fieldworks to generate some of the data and later took time to go through the work ensuring proper corrections and giving academic guidance to the work. The second author took samples, analysed and compiled the research work. Both authors read and approved the final manuscript.

\section{Funding}

Funding of the entire work was personal.

\section{Availability of data and materials}

The data sets used and analysed during the current study are available from the corresponding author on request.

\section{Competing interests}

The authors declare that they have no competing interests.

\section{Author details}

${ }^{1}$ Faculty of Physical Sciences, University of Nigeria, Nsukka, Nigeria. ${ }^{2}$ Faculty of Natural and Applied Sciences, Nasarawa State University, Keffi, Nigeria.

Received: 8 October 2019 Accepted: 5 January 2020

Published online: 04 February 2020

\section{References}

Akima H (1970) A new method of interpolation and smooth curve fitting based on local procedures. J ACM (JACM) 17(4):589-602

Azam S, Ito M, Chowdhury R (2013) Engineering properties of an expansive soil. Environmental Systems Engineering, University of Regina, Regina, pp 199202

Benkhelil J (1982) Benue trough and Benue chain. Geol Mag 119(2):155-168

Benkhelil J (1989) The origin and evolution of the cretaceous Benue trough (Nigeria). J Afr Earth Sci 8(2-4):251-282

Benkhelil J, Guiraud M, Ponsard JF, Saugy L (1989) The Bornu-Benue trough, the Niger Delta and its offshore: Tectono-sedimentary reconstruction during the cretaceous and tertiary from geophysical data and geology, Geology of Nigeria, 2nd edn. Rock view, Jos

British Standards 1377 (1990) Methods of test for soils for civil engineering purposes

Bureau of Indian Standards (1987) Standards India (Vol. 1). Bureau of Indian Standards

Burke K, Dewey JF (1974) Two plates in Africa during the cretaceous? Nature 249(5455):313

Burke K, Whiteman AJ (1973) Uplift, rifting and the break-up of Africa. Impl Cont Drift Earth Sci 2(part 7):735-755

Carter JD, Barber W, Tait EA, Jones GP (1963) The geology of parts of Adamawa Bauchi and Bornu Provinces in northeastern Nigeria. Bull Geol Surv 30:109

Chen FH (1965) The use of piles to prevent the uplifting of lightly loaded structure founded on expansive soil. Concluding proceedings engineering effects of moisture change in soils, International Research and Engineering Conference on expansive clay soils. A and M, Texas, pp 152-171

Chen FH (1988) Foundations on expansive soils. Elsevier, Amsterdam

Cratchley CR, Jones GP (1965) An interpretation of the geology and gravity anomalies of the Benue Valley, Nigeria Overseas, Geological Survey, Geophysical Paper No. 1

Dentith M (2011) Magnetic methods, airborne. In: Gupta HS (ed) Encyclopedia of solid earth geophysics, vol 1. Springer, Dordrecht, pp 761-766

Driscoll R, Crilly M (2000) Subsidence damage to domestic buildings. Lessons learned and questions asked. Building Research Establishment, London

Elarabi HA (2004) Factors influencing swelling behavior of expansive soils. J Building Road Res (BRRJ) 6:20-29

Fairhead JD (1986) Geophysical controls on sedimentation within the African rift systems. Geol Soc Lond Spec Publ 25(1):19-27

Fairhead JD, Binks RM (1991) Differential opening of the central and South Atlantic oceans and the opening of the west African rift system. Tectonophysics 187(1-3):191-203

Fairhead JD, Williams SE (2006) Evaluating normalised magnetic derivatives for structural mapping SEG 2006 New Orleans extended abstract
Fityus SG, Cameron DA, Walsh PF (2009) The shrink swell test. Geotech Test J 28(1):1-10

FAO (1998) World Reference Base for Soil Resources, by ISSS-ISRIC-FAO. World Soil Resources Report No. 84.

Freeman TJ, Burford D, Crilly MS (1991) Seasonal Foundation movements in London clay. Proceedings, 4th International Conference Ground Movements and Structures, Cardiff

Genik GJ (1992) Regional framework, structural and petroleum aspects of rift basins in Niger, Chad and the Central African Republic (CAR). Tectonophysics 213(1-2):169-185

Geosoft Inc. (2011a). MAGMAP Filtering. Technical Documentation. Tutorial. Geosoft Inc., Toronto, Canada. www.geosoft.com/support/downloads/ technicaldocumentation (accessed 20.03.12).

Geosoft Inc (2012) Oasis Montaj griddingwww.geosoft.com/resources/goto/oasismontaj-gridding. (Accessed 31 June 2013), p 20

GETECH Group PIc (2007) Advanced processing and interpretation of gravity and magnetic data, GETECH (geophysical exploration technology) group plc. Kitson House Elmete Hall, Leeds, p 22

Guiraud R, Maurin JC (1992) Early cretaceous rifts of Western and Central Africa: an overview. Tectonophysics 213(1-2):153-168

Holtz, R.D. \& Kovacs, W.D. (1981). An introduction to geotechnical engineering. Prentice-Hall, Upper Saddle River, USA.

Holtz WG (1969) Volume change in expansive clay soils and control by lime treatment. In: Proceedings of 2 nd international research and engineering conference on expansive clay soils, pp 157-174

Holtz WG, Gibbs HJ (1956) Engineering properties of expansive clays. Trans Am Soc Civ Eng 121:641-663

IS: 2720, Part 40 (1977) Indian standards methods of test for soils; determination of free swell index of soils. BIS, New Delhi

Janssen ME, Stephenson RA, Cloetingh SAPL (1995) Temporal and spatial correlations between changes in plate motions and the evolution of rifted basins in Africa. Geol Soc Am Bull 107(11):1317-1332

Lar UA, Tsalha MS (2005) Geochemical characteristics of the Jos-plateau basalts, north-Central Nigeria. Glob J Geol Sci 3(2):187-193

Macleod, W. N., Turner, D. C., \& Wright, E. P. (1971). The geology of the Jos Plateau, Vol. 1: General Geology. Geol. Surv. Nigeria Bull, 32.

Mokhtari M, Dehghani M (2012) Swell-shrink behavior of expansive soils, damage and control. Electr J Geotech Eng 17:2673-2682

Nelson JD, Miller DJ (1992) Expansive soils: problems and practice in foundation and pavement engineering. Wiley, New York

NOAA/NGDC (2010) World magnetic model - epoch 2010: Main field inclination. National Oceanic and Atmospheric Administration (NOAA)/National Geophysical Data Centre (NGDC), Colorado http://ngdc.noaa.gov/geomag/WMM/

Obaje NG (2013) Updates on the geology and mineral resources of Nigeria. Onaivi Printing and Publishing Co. Ltd, Abuja, pp 68-79

Ofoegbu CO (1984) A review of the geology of the Benue trough, Nigeria. J Afr Earth Sci 3(3):283-291

Olade MA (1975) Evolution of Nigeria's Benue trough (Aulacogen): a tectonic model. Geol Mag 112(6):575-583

Olayinka CO, Abiodun SO, Ayodeji O, Opeyemi J, Daniel OB (2017) Incessant building collapse in Nigeria: a framework for post-development management control. Dev Countries J 7(3):114-127

Phillips JD (2001) Designing matched band-pass and azimuthal filters for the separation of potential field anomalies by source region and source type. In: 15th geophysical conference and exhibition, Australian Society of Exploration Geophysicists, extended abstract, pp 1-4

Rahaman MA (1988) Recent advances in the study of the basement complex of Nigeria. In: Pre Cambrian geology of Nigeria, pp 11-41

Rajagopalan S (2003) Analytic signal vs. reduction to pole: solutions for low magnetic latitudes. Explor Geophys 34(4):257-262

Ridsdill-Smith TA (1998) Separating aeromagnetic anomalies using wavelet matched filters. In: SEG technical program expanded abstracts 1998, pp 550553 Society of Exploration Geophysicists

Schull TJ (1988) Rift basins of interior Sudan: petroleum exploration and discovery. AAPG Bull 72(10):1128-1142

Sheriff RE (2002) Encyclopedic dictionary of applied geophysics, 13 geophysical reference series, 4th edn. Society of Exploration Geophysicists, Tulsa, p 429

Snethen DR, Johnson LD, Patrick DM (1977) An evaluation of expedient methodology for identification of potentially expansive soils. Report no. FHWA-RD-77- 94, U.S. Army engineer waterways Experiment Station, USAEWES, Vicksburg 
Spector A (1968) Spectral analysis of aeromagnetic maps: Ph.D. thesis. Dept. of Physics, University of Toronto

Syberg FJR (1972) A Fourier method for the regional-residual problem of potential fields. Geophys Prospect 20(1):47-75

Thomas PJ, Baker JC, Zelazny LW (2000) An expansive soil index for predicting shrink-swell potential. Soil Sci Soc Am J 64(1):268-274

Umbugadu AA, lgwe O (2019) Mineralogical and major oxide characterization of Panyam clays, north -Central Nigeria. Int J Phys Sci 14(11):108-115

Wasiu J, Oyebola OJ, Victor B (2014) Causes of building collapse and prevention in Nigeria. In: 11 th international conference and annual general meeting of Nigerian Institute of Civil Engineers, pp 7-8

Whiteman AJ (1982) Nigeria: its petroleum geology resources and potential: Graham and Trotman. London 1(1):350

Wijins C, Perez C, Kowalezyk P (2005) Theta map: edge detection in magnetic data. Geophysics 70:L39-L43

Wright JB (1976) Volcanic rocks in Nigeria. Geology of Nigeria, 2nd edn. Abiprint Ltd, Ibadan, p 125

Wright JB (1981) Review of the origin and evolution of the Benue trough in Nigeria. Earth Evol Sci 1(2):98-100

\section{Publisher's Note}

Springer Nature remains neutral with regard to jurisdictional claims in published maps and institutional affiliations.

\section{Submit your manuscript to a SpringerOpen ${ }^{\circ}$ journal and benefit from:}

- Convenient online submission

- Rigorous peer review

- Open access: articles freely available online

High visibility within the field

- Retaining the copyright to your article

Submit your next manuscript at $\boldsymbol{\nabla}$ springeropen.com 